\title{
Seismic stratigraphy of Dinantian carbonates in the southern Netherlands and northern Belgium
}

\section{John J.G. Reijmer ${ }^{1,2, *}$, Johan H. ten Veen ${ }^{3}$, Bastiaan Jaarsma ${ }^{4}$ \& Roy Boots ${ }^{1}$}

1 Sedimentology and Marine Geology group, Geology and Geochemistry cluster, Faculty of Earth and Life Sciences, Vrije Universiteit Amsterdam, De Boelelaan 1085, 1081 HV Amsterdam, the Netherlands.

2 Present address: College of Petroleum Engineering \& Geosciences, King Fahd University of Petroleum \& Minerals, Dhahran 31261, Saudi Arabia

3 TN0 - Geological Survey of the Netherlands, Princetonlaan 6, 3584 CB Utrecht, the Netherlands

4 EBN B.V., Daalsesingel 1, 3511 SV Utrecht, the Netherlands

* Corresponding author. Email: j.j.g.reijmer@vu.nl

Manuscript received: 3 June 2017, accepted: 22 September 2017

\section{Abstract}

Due to their potential as a petroleum or geothermal system, the Dinantian carbonates of the Netherlands have recently attracted renewed interest because of the identified presence of excellent reservoir properties. This notion contrasts with the general assumption that these carbonates are tight. Therefore, in order to give the current knowledge state, this paper re-examines the sparse publicly available well and seismic data and literature to assess the distribution and reservoir properties of the Dinantian carbonates.

Dinantian carbonate deposition occurred throughout the study area (southern onshore and offshore of the Netherlands and northern Belgium), which is situated on the northern margin of the London-Brabant Massif, progressively onlapping the latter structure. This study confirms the presence of three carbonate facies types in the study area: a Tournaisian low-gradient carbonate ramp system, succeeded by a succession in which the carbonate ramp system evolved to a rimmed shelf setting. Subsidence of the northern margin of the London-Brabant Massif resulted in a landward shift of the shallow-marine facies belts, while the formation of normal faults resulted in a 'staircase'-shaped shallow-water platform-slope-basin profile, associated with large-scale resedimentation processes. After deposition, the limestone deposits were frequently exhumed and reburied. A first period of regional exhumation occurred at the end of the Dinantian, which seems to be associated with porosity-enhancing meteoric karstification, possibly limited to the palaeo-shelf edge. The most intense alterations seem to be present as a deep leached horizon below the Cretaceous unconformity at the top of the Dinantian sequences. In addition, clear evidence for hydrothermal fluid migration is found locally, enhancing reservoir properties at some places while occluding porosity at others. The timing of these phases of hydrothermal fluid circulation is poorly understood.

Whereas in the United Kingdom hydrocarbons have been produced from karstified Dinantian carbonates, this petroleum play has received little attention in the Netherlands. This paper shows that, also for the Netherlands, a karstic reservoir probably existed before the start of hydrocarbon generation from the onlapping basal Namurian shales. The hydrocarbon prospectivity of these sediments, however, is primarily controlled by the presence of both a karst-related reservoir and migration routes from a decent-quality source rock. Two geothermal projects producing from this reservoir in the southern onshore Netherlands have shown the potential of the Dinantian carbonates for ultra-deep geothermal projects. To conclude, the findings presented herein are relevant for studies of the hydrocarbon prospectivity and studies of the geothermal potential of Dinantian carbonates in the Dutch on- and offshore.

Keywords: carbonates, Dinantian, Dutch subsurface, reservoir properties

\section{Introduction}

This study assesses the Lower Carboniferous Dinantian microbial platform carbonates in the Dutch subsurface. In most parts of the Netherlands the Dinantian rock formations are relatively under-explored and a petroleum system is not proven. Only limited well control exists and most of the wells are clustered around the margins of the Carboniferous basin (Kombrink, 2008; 


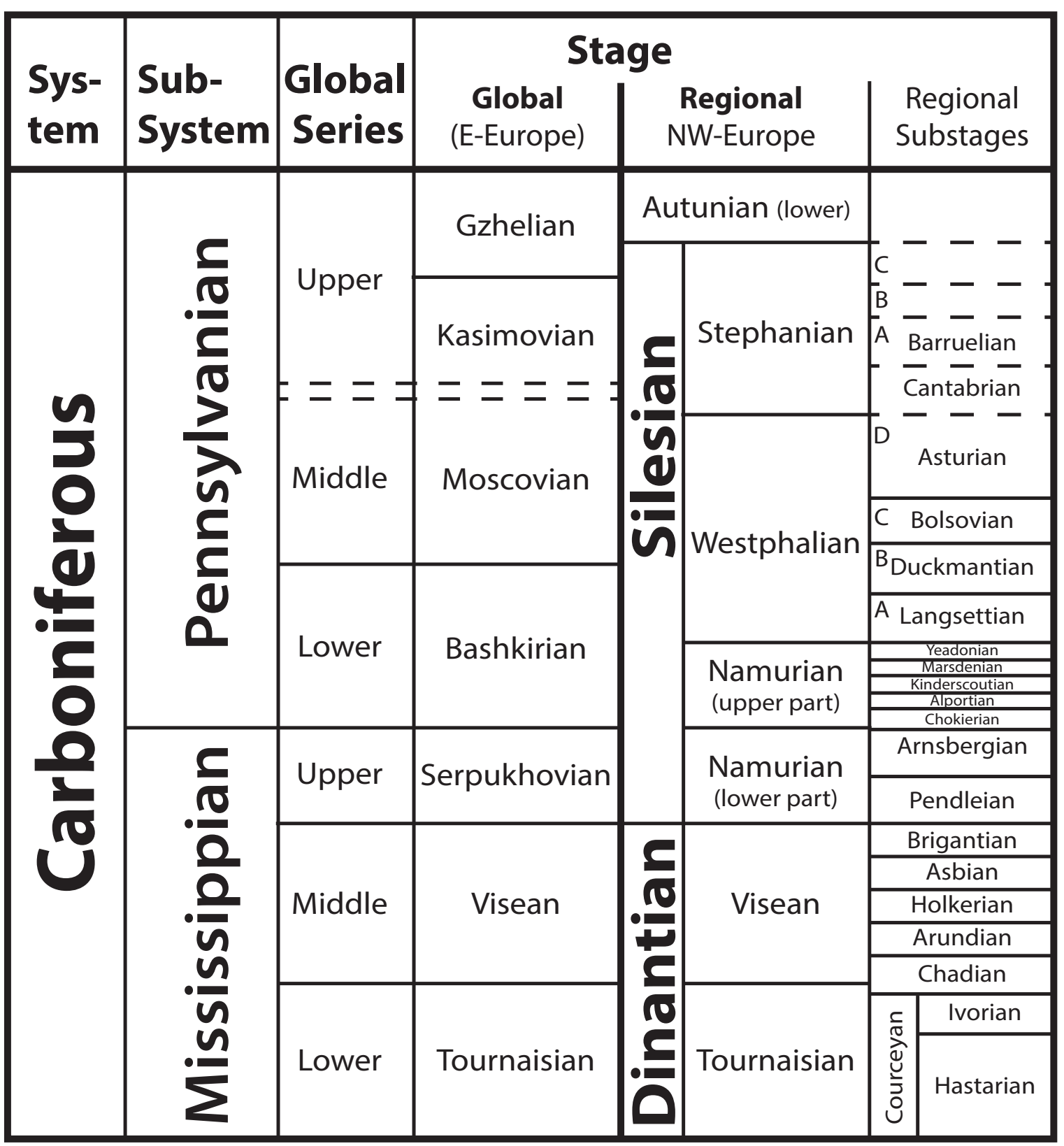

Fig. 1. Carboniferous System global series and stage subdivision with global subdivisions and substage subdivisions in Western Europe. Belgian substage names shown for Tournaisian, and British substage names for Visean. Dashed lines separating Middle and Upper Pennsylvanian Series (Moscovian and Kasimovian Stages) reflect range of correlation uncertainty of the boundary. Dashed lines in regional columns reflect uncertainty of correlation with global stages. Modified from Heckel \& Clayton (2006).

Van Hulten \& Poty, 2008). Additionally, seismic coverage is poor because most seismic data were acquired and processed with a focus on the younger, shallower formations that are known to host significant amounts of hydrocarbon accumulations (Van Hulten \& Poty, 2008).

During the Dinantian (Fig. 1) the deposition of platform carbonates and deep marine shales and chert layers in areas of low clastic input predominated in NW Europe. Areas in the vicinity of clastic sources were characterised by shallow- and deepwater deltaic and turbidite deposits (Van Hulten \& Poty, 2008). Many of the major Late Palaeozoic basins in other parts of the world are characterised by similar depositional sequences. The structural setting during the Early Carboniferous steered the Dinantian sediment deposition (Fig. 2) in which the highs were preferential sites of carbonate-platform growth. The lineaments of these highs followed the old Caledonian sutures. The flanks of the London-Brabant Massif also constituted such highs. It is thought that Namurian organic-rich basinal shales onlapping the Dinantian carbonate platforms and/or the platformintercalated Dinantian shales could have provided hydrocarbon charge to the Dinantian limestones (Figs 3 and 4; TOTAL, 2007; Van Hulten \& Poty, 2008). 


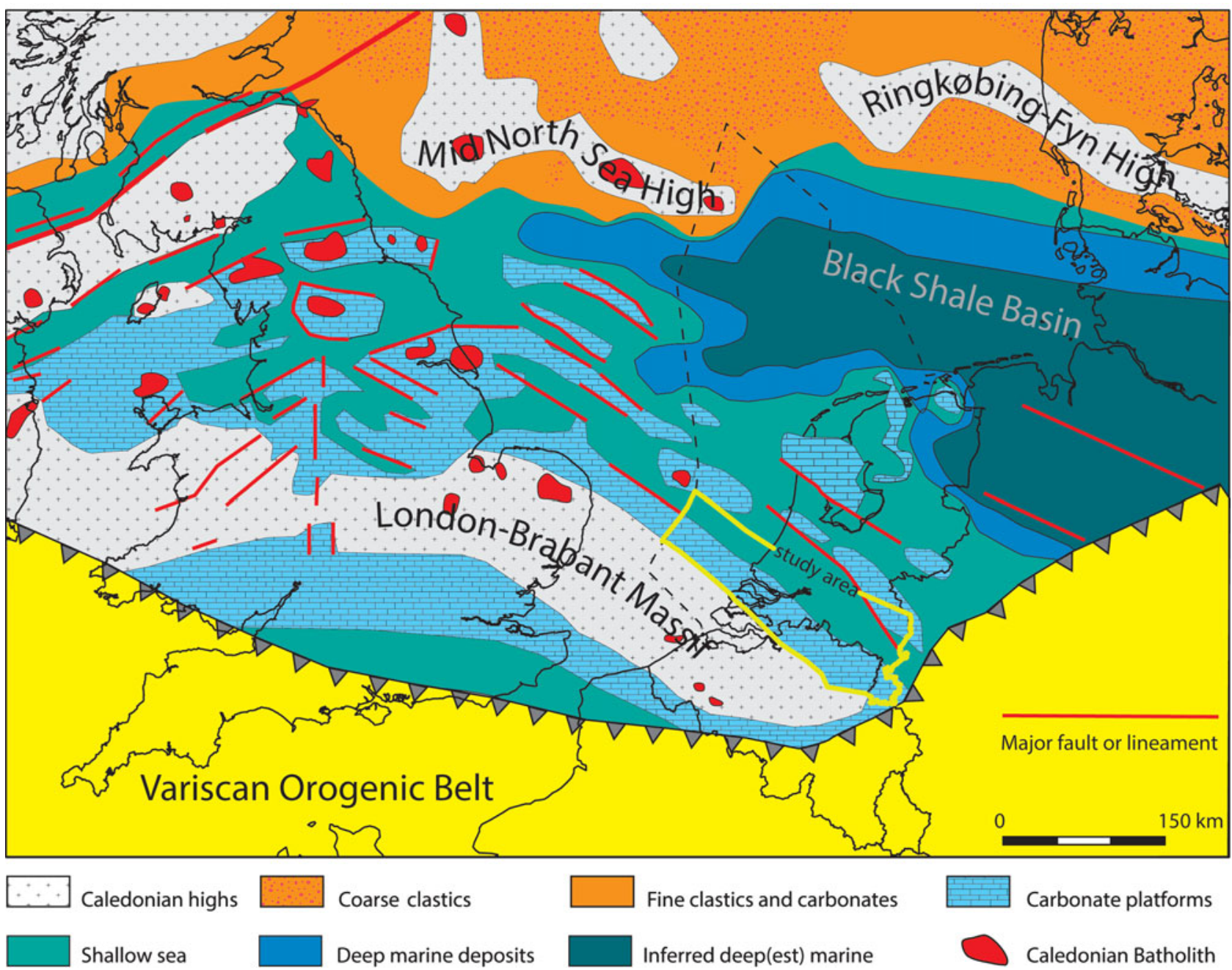

Fig. 2. European map of Dinantian palaeogeography. Study area marked by yellow box. From Van Hulten (2012).

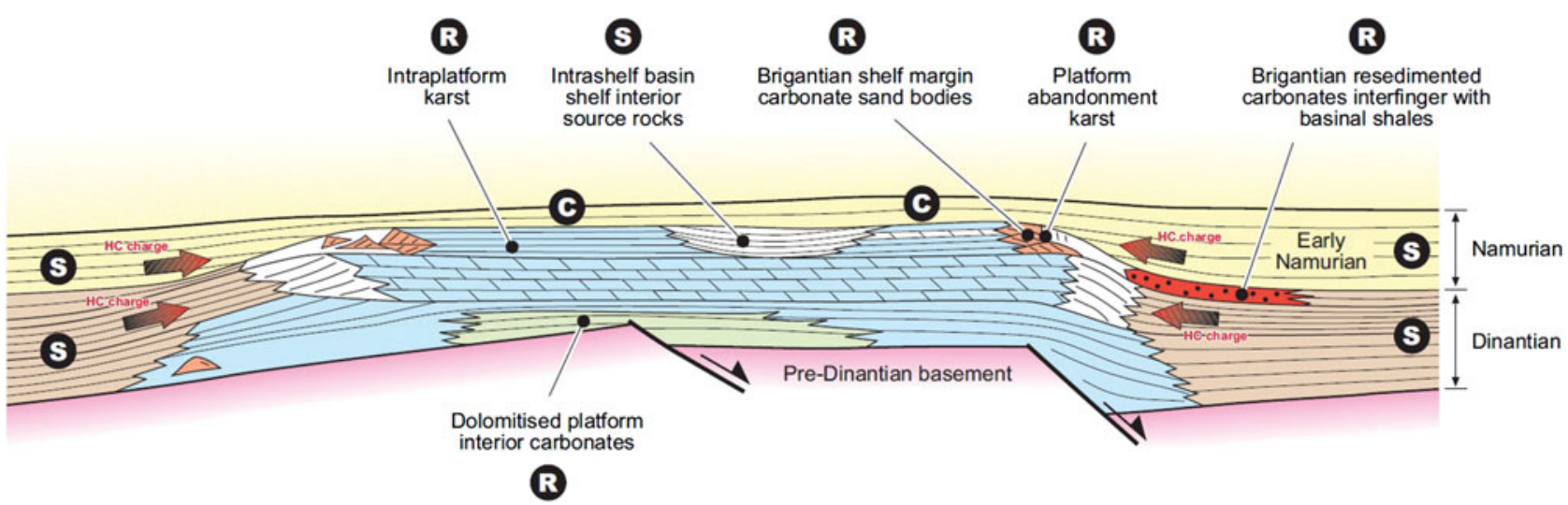

Fig. 3. Schematic section showing the components of the inferred Dinantian petroleum system. R: reservoir rock; S: seal rock; C: organic carbon. From TOTAL (2007).

A recent re-evaluation of the Dinantian petroleum system on the northern flank of the London-Brabant Massif showed a cluster of leads in the Dinantian carbonates straddling the UK-NL median line (Jaarsma et al., 2013). Small amounts of oil have been produced from the Dinantian limestones, onshore England (TOTAL, 2007), while oil shows were recorded in well 53/12-2 in the UK offshore (Cameron, 1993). Despite the lack of proven economic hydrocarbon occurrences in the southern North Sea, the Dinantian carbonates are still considered potential hydrocarbon prospects (Cameron \& Ziegler, 1997; Van Hulten \& Poty, 2008; Jaarsma et al., 2013). 


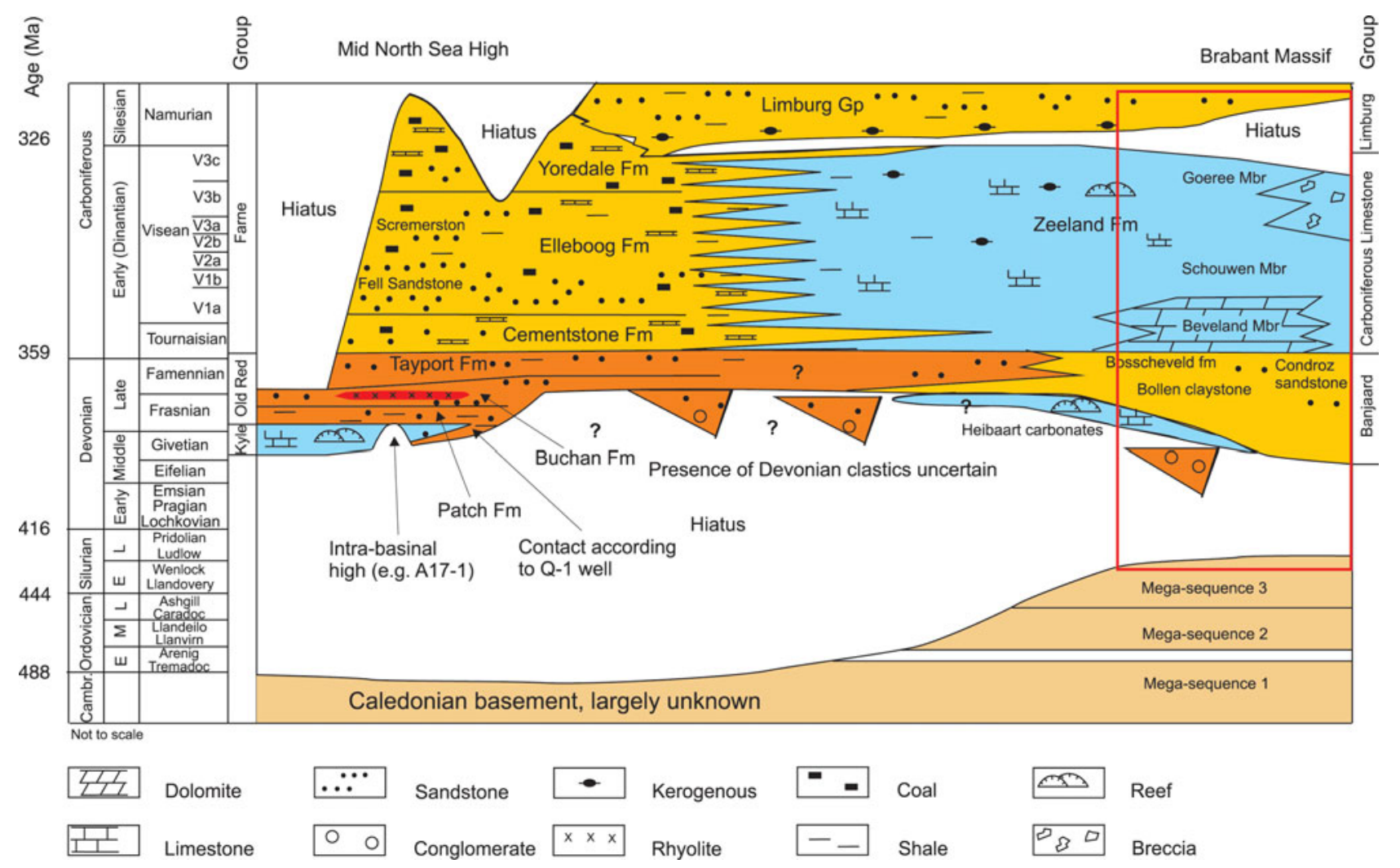

Fig. 4. Schematic distribution of the Pre-Silesian rocks in the Dutch subsurface. Rectangle marks the stratigraphy encountered in the study area. From Geluk et al. (2007).

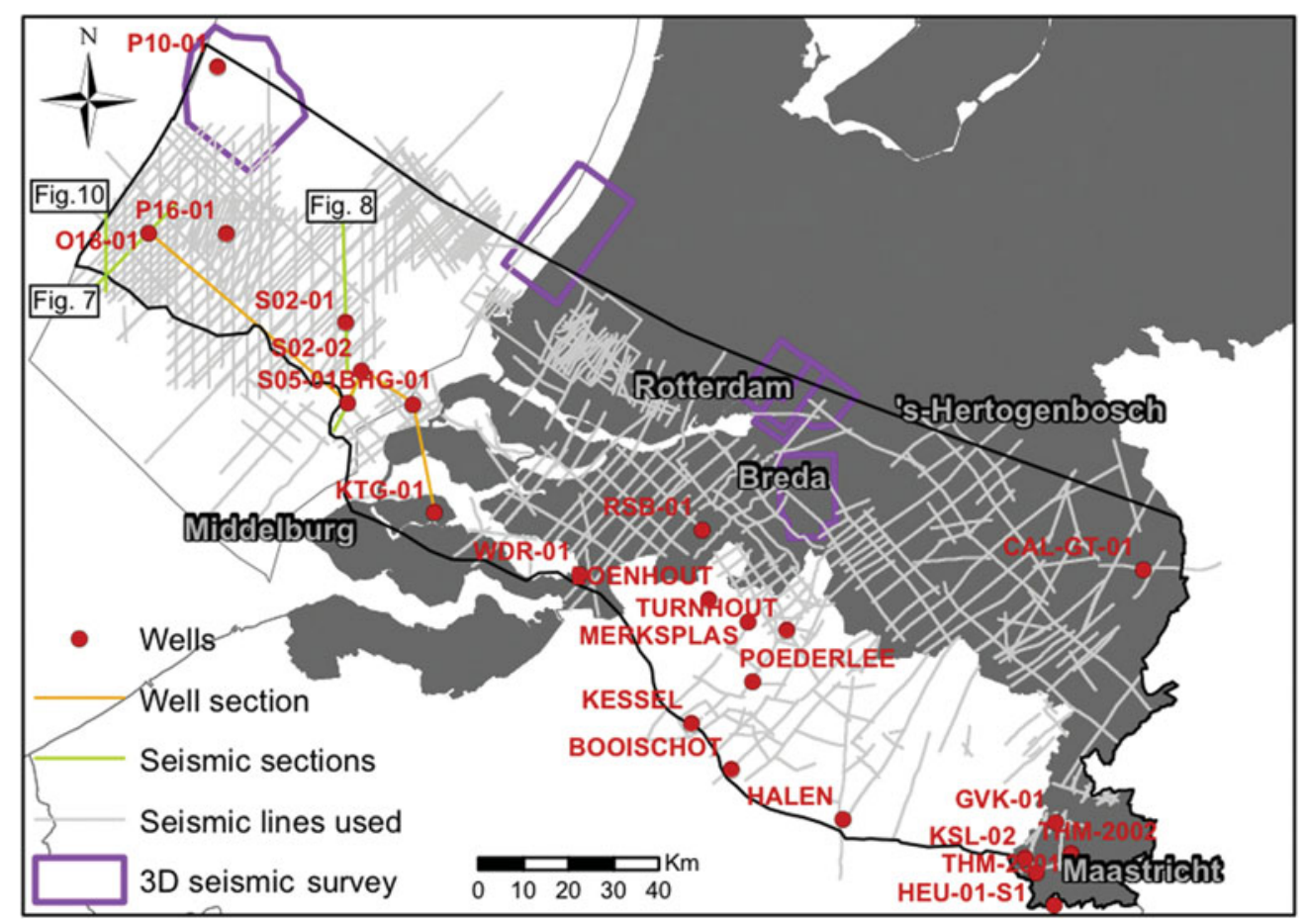

Fig. 5. Map view of seismic and well data used and location of data shown in subsequent figures. 
The drilling of geothermal well CAL-GT-01 near Venlo (Fig. 5) in the Dutch southern onshore in 2012 revealed the presence of Dinantian carbonates with better than expected reservoir properties (Jaarsma et al., 2013). Based on the analysis of drill cuttings, these increased reservoir properties can probably be attributed to hydrothermal karstification (Poty, 2014) due to the flow of fluids with temperatures higher than the ambient matrix temperature, so-called hypogene karst processes following Klimchouk (2017). In several wells and in seismic data along the London-Brabant Massif, evidence for major karst features (intra- and top platform) was also found (Jaarsma et al., 2013). In Belgium, Dinantian carbonates with good reservoir properties are known from the underground gas storage (UGS) facility near Loenhout and the Merksplas-Beerse geothermal doublet (Fig. 5). All sites utilise a karstified Dinantian reservoir with porosities up to $20 \%$ and two Darcy permeabilities (Vandenberghe et al., 2000; Jaarsma et al., 2013). The occurrence of locally improved reservoir properties contrasts with the notion of the generally tight character of the Dinantian carbonates in the Dutch subsurface.

This study focuses on increasing the knowledge of the distribution of Dinantian reservoir properties related to palaeogeography, depositional setting, diagenesis (mineralisation, dolomitisation), karstification and fracturing. It aims to summarise the reservoir potential, for hydrocarbon and geothermal purposes, of the Dinantian succession in the area north of the LondonBrabant Massif in relation to its palaeogeographical setting both during and after deposition. A model for the regional distribution and development of the Dinantian carbonates was obtained that integrates core observations, well correlation, seismic interpretation and a comparison with analogues to evaluate the facies variations and karstification of the Dinantian carbonates. This model should serve the exploration for hydrocarbons and research into the potential of ultra-deep geothermal in the Dinantian carbonates.

\section{Early Carboniferous (Dinantian) sedimentological development of NW Europe}

The Northwest European Carboniferous Basin (NWECB; Fig. 2) developed in the Devonian and Carboniferous in response to lithospheric stretching and Late Carboniferous flexural subsidence (Kombrink et al., 2008a,b) between the southern margin of the Old Red Continent to the north and the Variscan orogeny to the south, which more or less agrees with the southern margin of the Rhenohercynian Zone (Ziegler, 1990a,b; Oncken et al., 1999; Burgess \& Gayer, 2000; Narkiewicz, 2007). The basin consisted of a series of WNW-trending half-grabens in the southern North Sea, in which a thick pile of Devonian and Lower Carboniferous sediments was deposited sourced from the Mid German Crystalline High in the south and the Old Red Continent in the north (Fig. 4). According to Fraser \& Gawthorpe (1990), $\mathrm{N}-\mathrm{S}$ extension led to the formation of the $\mathrm{E}-\mathrm{W}$-trending British Graben, whereas the NW-trending structures were reactivated. The origin of the extension is either related to back-arc extension in the Rheno-hercynian Basin situated to the southeast of the Netherlands (e.g. Ziegler, 1990b) or escape tectonics (Coward, 1993).

The resulting horst-and-graben tectonic style steered the occurrence of isolated carbonate build-ups on intra-basinal highs. In the UK, these highs agree with the distribution of postCaledonian granite batholiths (Fig. 2), while the extension was accommodated along Caledonian structural weakness zones. This extensional style extends into the UK and Dutch offshore area (Bless et al., 1983; Kombrink, 2008; Van Hulten \& Poty, 2008). The northern part of the NWECB received abundant siliciclastic input from the Caledonian mountains in the north and west.

Throughout the Dinantian period the London-Brabant Massif played a vital role as a relatively stable high at the southern border of the Carboniferous Basin (Fig. 2; Kombrink et al., 2010). Due to tectonic activity, the high underwent uplift, fracturing, emersion, and karstification at several moments during the Dinantian. This resulted in a configuration with carbonate build-ups developing on the footwall block, while hanging-wall blocks were filled by deeper water slope deposits (Fig. 3; Fraser \& Gawthorpe, 1990; Bridges et al., 1995; T0TAL, 2007). These downthrown blocks adjacent to carbonatedominated highs were often intervening low areas, where more basinal fine-grained siliciclastic sediments, such as the Bowland Shale, were deposited. Van Hulten (2012) proposed that a large area of the present North Sea area north of the Netherlands was a (black) shale basin during the Dinantian, based on magnetotelluric data. However, there are no well data to support this view.

The carbonate deposits of the Early Carboniferous are not dominated by framework-builders, since this type of carbonateproducing organism became extinct during the late Devonian 'Kellwasser' event (Buggisch, 1991; Aretz \& Chevalier, 2007). The main types of carbonate build-ups are microbial mud-mounds (Bridges et al., 1995), the product of an M-factory type of carbonate deposition (Schlager, 2005). The depositional environment changed during the Dinantian in response to the main tectonic basin-forming phases and variations in sea level, which is reflected by the different types of carbonate mud-mounds that developed through time (Bridges et al., 1995).

The first basin-forming period documented in the UK is the Tournaisian (Late Devonian to Late Courceyan stage; Fig. 1), during which fluvial-deltaic deposits were derived from the basin margins. Initial carbonate deposition started in the Tournaisian to Tournaisian-Visean (Chadian stage; Fig. 1) and was characterised by alternations of fluvial, marginal marine and nearshore siliciclastics with carbonates. The deeper basin was characterised by a carbonate ramp where Waulsortian mounds could develop (Bridges et al., 1995; TOTAL, 2007). During the 
Early Visean (Late Chadian to Late Holkerian stages; Fig. 1) the carbonate depositional environment evolved from a carbonate ramp that developed on the exposed basement blocks to a progradational rimmed carbonate shelf (Aretz \& Chevalier, 2007; Kombrink, 2008). During the later Dinantian (Late Asbian to Early Brigantian stages; Fig. 1) the distinction between the carbonate shelf and basin areas became more pronounced. The rimmed carbonate platforms that developed on the shelf areas formed a clear topographic contrast with the basins (Muchez et al., 1990). In these basins deep marine conditions prevailed with deposition of calciturbidites and siliciclastic mudstones (TOTAL, 2007). Near the edges of the carbonate platforms, which became steeper during the Visean, coarse breccias and boulder beds were deposited. In many locations the Brigantian deposits are missing and the related unconformity is widespread and associated with karst features (Gallagher \& Somerville, 2003; T0TAL, 2007). Platforms on intra-basinal highs drowned, halting carbonate deposition before the end of the Visean (Waters et al., 2009; Van Hulten, 2012; Hoornveld, 2013).

The Dutch Dinantian carbonates are grouped in the Zeeland Formation, which is subdivided into the Beveland, Schouwen and Goeree Members (Van Adrichem Boogaert \& Kouwe, 1993) (Fig. 4). Carbonate development remained restricted to emergent highs. The time-equivalent deposits to the Zeeland Formation in the Dutch northern offshore, the Farne Group, can be subdivided into the Cementstone, Elleboog and Yoredale Formations (Fig. 4). They comprise an assemblage of alternating claystones and sandstones with minor development of coal layers and variable amounts of intercalated carbonate beds deposited within paralic to shallow marine environments (Geluk et al., 2007). The transition between the carbonate and siliciclastic facies types cannot be positioned accurately due to a lack of data. This zone probably migrated southward with time. A full description of all stratigraphic units of the Early Carboniferous period can be found in the 'Stratigraphic Nomenclature of the Netherlands' (Van Adrichem Boogaert \& Kouwe, 1993) and 'Chapter 5: Carboniferous and Devonian of the Southern North Sea' from the 'Lithostratigraphic Nomenclator of the UK North Sea' (Cameron, 1993).

For the Netherlands, a two-stage model was proposed for the development of the Dinantian carbonates on the northern flank of the London-Brabant Massif based on a series of wells drilled in the 1980s, which include Brouwershavensegat (BHG01), offshore well S05-01 and Kortgene (KTG-01) (NAM, 1982). This depositional model only describes the development of the Lower Carboniferous carbonates on the northern margin of the London-Brabant Massif that constituted the southern boundary of the Northwest European Carboniferous Basin. This area was mostly influenced by subsidence caused by loading of the Variscan foreland (Kombrink, 2008).

The first stage spans the Tournaisian to Early Visean and is characterised by a cyclic development in which massive dolomite and nodular anhydrite were deposited in a lagoonal setting with a large supratidal flat area. The model proposed a grainstone barrier or island complex to separate the vast low-relief peritidal setting from the slope area that was characterised by carbonate mud-mounds and Waulsortian reef development below wave base. Further basinwards an extensive shale basin is proposed (NAM, 1982).

The second (transgressive) stage spans the Middle and Late Visean periods and is characterised by a landward shift of facies patterns. The extent of the exposed supratidal flat is reduced while the exposed London-Brabant Massif is progressively onlapped. A proper carbonate platform developed with a grainstone barrier at the platform margin that aggraded up to sea level, protecting a broad intertidal lagoon. This protective barrier also slightly retrograded, allowing carbonate mud-mounds situated on the slopes below wave base to develop over areas previously occupied by shallower facies. The slope angles steepened, and at the deeper parts of the slope and within the basin characteristic 'Culm/Kulm' shales (Kombrink, 2008; Aretz, 2016) were deposited.

For the northern part of the Netherlands, Kombrink (2008) presented the first seismic images through three Dinantian flattopped carbonate build-ups with well-developed slopes. The mapped platform in offshore block M09 is still undrilled. The onshore wells Luttelgeest (LTG-01) and Uithuizermeeden (UHM2) penetrated the Dinantian carbonates and showed a stratigraphy comparable to that known from Belgium (Abbink et al., 2009; Van Hulten \& Poty, 2009). The well-to-well correlation of Van Hulten (2012) showed, however, that the upper part of the Visean stratigraphy was missing in LTG-01, while neither well encountered the Tournaisian section commonly present in wells to the south (the study area). Depositional cycles recognised in the thick carbonate successions could be regionally correlated to those known from Belgium (Van Hulten, 2012). Sparked by these findings, Hoornveld (2013) re-evaluated the Dinantian carbonates in the northern part of the Netherlands and identified four individual Visean carbonate build-ups: the Uithuizermeeden, Fryslân, Luttelgeest and Muntendam platforms.

\section{Well data analysis}

Well logs covering the entire Dinantian interval are scarce. Five wells with sufficient well log data were correlated using gammaray, sonic, lithologic and biostratigraphic logs (see Fig. 6). These wells, 018-01, S05-01, S02-02, BHG-01 and KTG-01 (Figs 5 and 7), were drilled for hydrocarbon exploration in the late 1970 s to early '90s. The cored intervals were examined and compared to previous core descriptions, thin section descriptions, carbonate depositional models and literature publicly available on the Dutch Oil and Gas Portal (nlog.nl) or in the NAM core repository. The description of the carbonate cores was made using the carbonate classification scheme of Dunham (1962), while the porosity of the carbonate sediments was described using the 


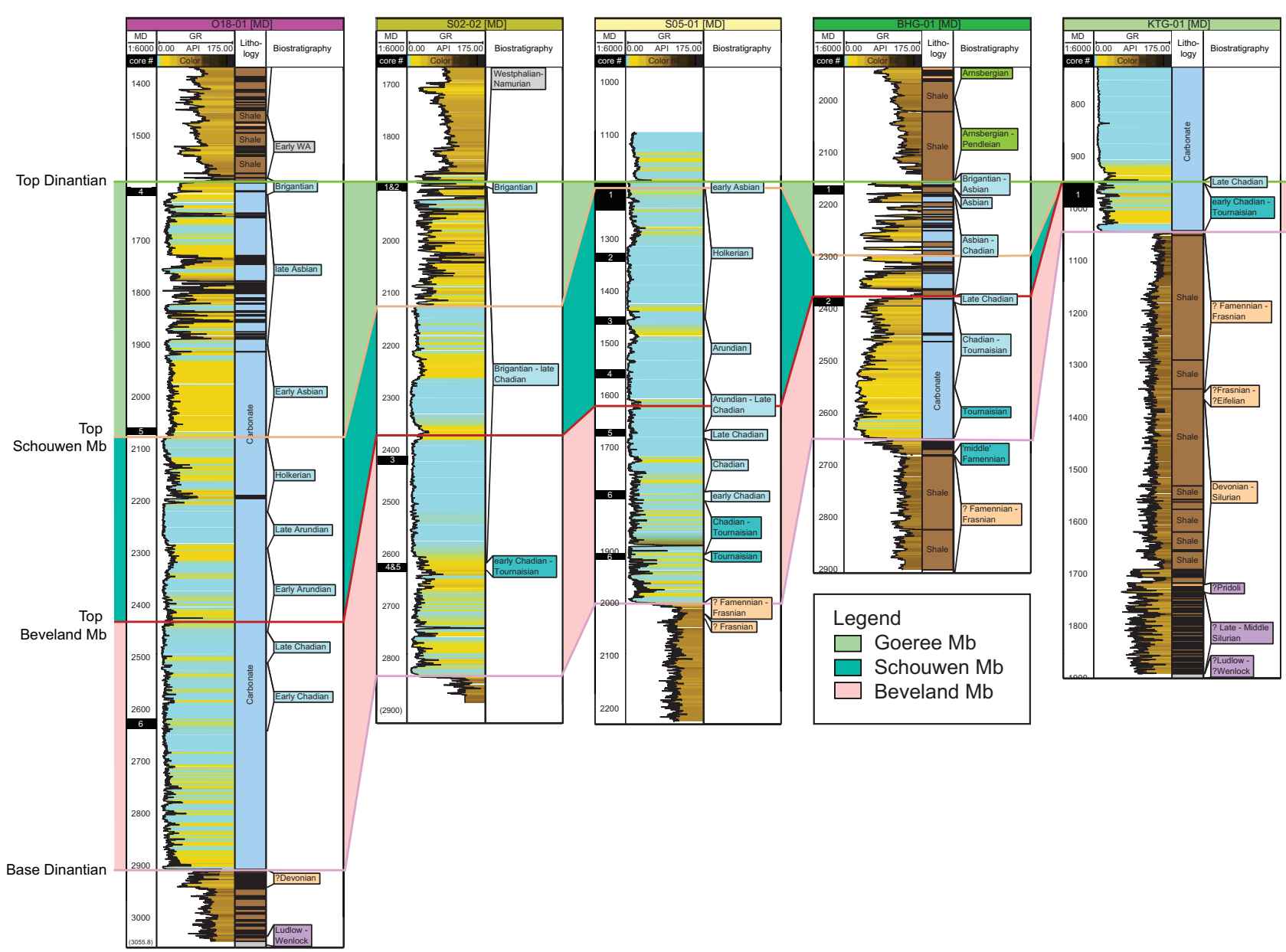

Fig. 6. Well correlation panel through wells 018-01, S2-02, S05-01, BHG-01 and KTG-01 (see Fig. 5 for locations), flattened on top Dinantian. Gamma-ray, sonic, lithology and biostratigraphy logs are shown.

porosity classification system of Choquette \& Pray (1970). The geothermal well CAL-GT-01, drilled in 2012, was included in this comparison, using the analysis of well cuttings (Poty, 2014). Composite logs of wells from the Belgian Campine Basin that reached the Dinantian limestones or the Lower Namurian strata were also studied (Fig. 5). These were not incorporated in the well correlation panel, mainly because of the lack of well data.

\section{Core description}

\section{8-01}

Description Three cores were taken in 018-01. The succession in cores \#6 to \#4 shows dolomitised mud-to wackstones (Fig. 7A) with some mouldic porosity at the base, to microbial mudstones with reworked and lithified bioclasts at the top (Swennen \& Muchez, 1991). The carbonates contain some diagenetic chert; stylolites occur throughout but are especially abundant at the top (1604-1600 m) where oil-stained cavities are also present (Table S1, in supplementary material available online at https://doi.org/10.1017/njg2017.33). All depths are in measured depth (MD).

Interpretation The sediments present in the core were deposited in an open marine environment, probably during the Early Visean (Table S1; Swennen \& Muchez, 1991). The carbonates originally consisted of rhythmic alternations of mud- to wackestones and grain- to packstones, probably deposited below and near wave base on a low-relief shelf area during the Tournaisian and Early Visean (Courceyan to Chadian), and were subsequently partly dissolved and dolomitised. A similar succession was found in the lower section of the S02-02 well (Fig. 7A). Swennen \& Muchez (1991) propose an Early Visean or Late Visean period of emergence, which agrees with regionally recognised sea-level lowstands (Waters \& Davies, 2006) and corresponds to the timing of development of massive dolomites in the Early Dinantian in the Campine Basin (Muchez \& Viaene, 1994).

The middle part of the succession contains bioturbated bioclastic wacke- to packstones and clay-rich layers characteristic of slow sedimentation prevailing in an open marine environment 

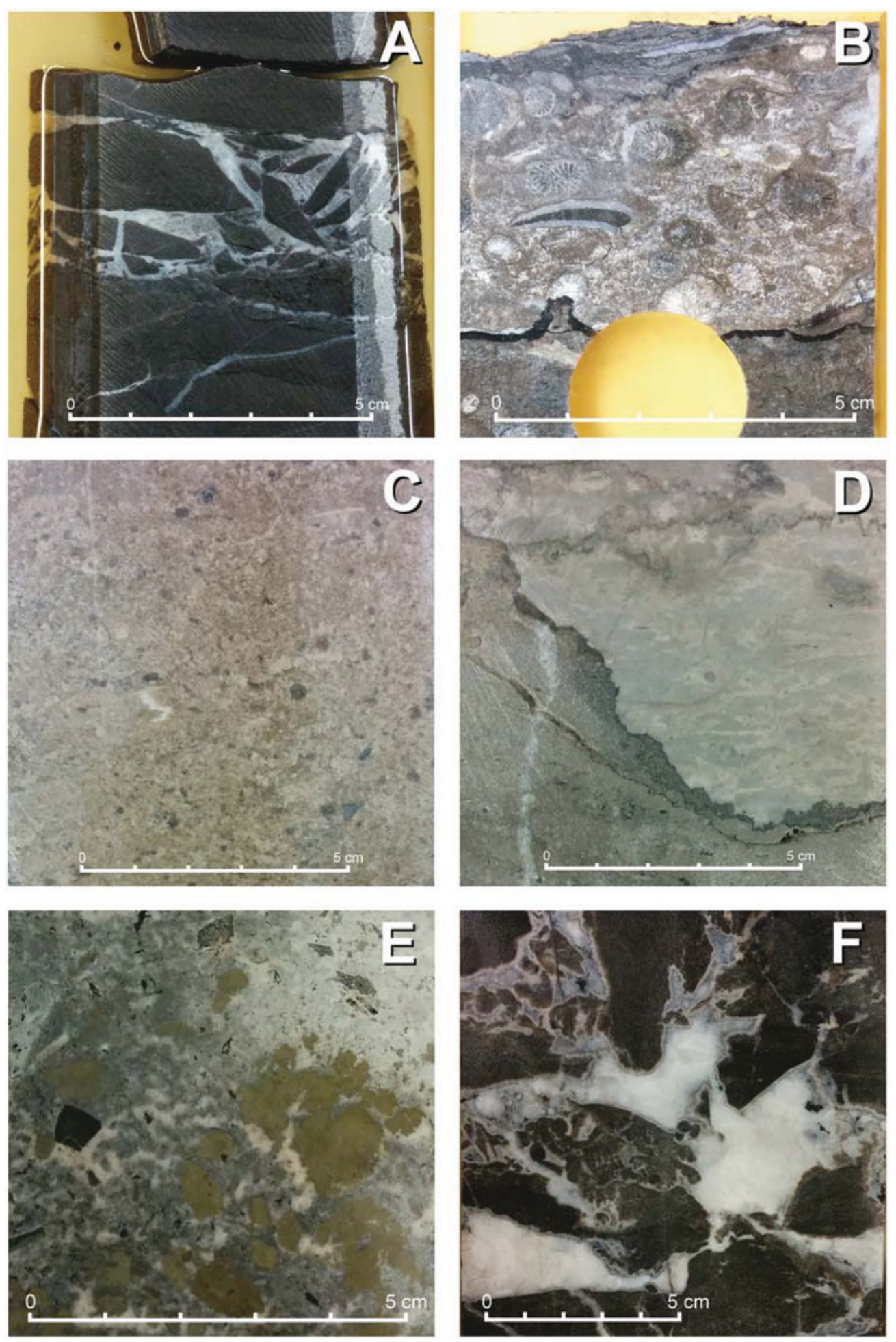

Fig. 7. Selection of core photographs depicting characteristic lithofacies encountered. All photographs include a scale in $\mathrm{cm}$. (A) Lithofacies D1; brecciated carbonate filled with vein cement, found in well 018-01 (2635.3 m). (B) Lithofacies D2; silicified coarse bioclastic grainstone containing abundant (cm-sized) crinoidal and thick shell debris, found in core S05-01 (1565.0 m). (C) Lithofacies D2; top of core S05-01 $(1190.0 \mathrm{~m})$, clean grainstone, containing abundant bioclastic debris. (D) Lithofacies D3; coarse carbonate breccia in core BHG-01 (2181.5 m); note stylolitic surface at contact between boulders. (E) Lithofacies D3; intensely mineralised carbonate breccia in core BHG-01 (2177.0 m), containing abundant pyrite and some siliciclastic shale clasts. (F) Lithofacies D1; mineral aggregates filling cavernous porosity relict of brecciation in well KTG-01 $(984.5 \mathrm{~m})$. 
below wave base during the Chadian to Holkerian stages of the Middle Visean (Swennen \& Muchez, 1991).

The top part of the succession shows 'reefal' limestone deposited before the Visean to Namurian emergence. The litho- to bioclastic character and high angle of deposition suggests that these sediments were deposited on the flank/slope of a carbonate build-up (Swennen \& Muchez, 1991) during the late Asbian. The presence of hydrocarbon traces indicates that charging occurred during or after the development of the fracture porosity. A similar, somewhat higher-energetic, facies developed in the top of well S02-02. Similar, time-equivalent build-ups are known from Derbyshire platform and Campine Basin on the flank of the London-Brabant Massif (Swennen \& Muchez, 1991). The clay-rich intervals present show some silicification related to compaction (Swennen \& Muchez, 1991). The sedimentary facies encountered in this core corresponds to that of an M-type carbonate factory, wherein bacterially induced precipitation of carbonate and seawater diagenesis are the dominant build-up forming processes (Schlager, 2005; Della Porta et al., 2008, 2013).

\section{S02-02}

Description Five cores were taken in S02-02; the descriptions partly rely on Dronkers et al. (1984) and Cambridge Carbonates (2002). The base of the sequence (core \#5) consists of dark-grey to black mudstones, alternating with pack- and wackestones rich in oncoids (1-5 mm) and some centimetre-sized bioclasts. Horizontal stylolites are present. Around $2629 \mathrm{~m}$ an exposure surface was found on top of an ooid-rich grainstone bed. The top of the core shows abundant, up to centimetre-sized, shell fragments, and coated grains, high-angle calcite veins, horizontal stylolites and microstylolites are common. Core \#4 is very similar and contains dominantly black wackestones, with occasional lithoclasts; the whole core is heavily brecciated. Core \#3 is not described due to the small amount of material preserved.

The succeeding sequence (core \#2) shows grey pack- to grainstones with abundant bioclasts, e.g. millimetre-sized crinoids and shells, fine-grained limestone intraclasts, and ferroan minerals. Millimetre-sized isolated mouldic to fenestral porosity has developed, but pore connectivity is poor. The core continues with (at $1891.3 \mathrm{~m}$ ) decimetre-sized clasts, bounded by algal mudstone and peloidal floatstone. Algal boundstone with centimetre- to decimetre-sized clasts filled by fine-grained carbonate mud tops this part of the core. The contacts between the individual carbonate clasts show distinct compaction features. The very top of the cored interval (core \#1) contains resedimented carbonate rocks, very similar to the sediments found in core \#2.

Interpretation The carbonate sediments in this well show a deepening upwards trend (Table S1). The base of the sequence contains nearshore deposits such as restricted marine dolomites. These are overlain by semi-restricted lagoonal wackestones and packstones with coated grains and bored shells, deposited in shallow subtidal to intertidal environments (Cambridge Carbonates, 2002) where sediment accumulation was probably slow. Temporary exposure led to development of pedogenic structures. These deposits are considered to be of Tournaisian to Early Visean (Chadian) age by their lithological resemblance to the lower part of KTG-01 and BHG-01 wells (Cambridge Carbonates, 2002). The grainstones, overlying these lagoonal sediments, indicate higher-energy deposits that represent an open marine platform margin setting. Seaward of this platform margin open marine shelf packstones were deposited. On the deeper parts of the shelf slope, microbial mud-mounds developed that alternate with redeposited carbonate debris derived from the platform margin or slope build-up facies. This sequence is very similar to sedimentation patterns known from the Lower Carboniferous carbonates from the Caspian region as described by Kenter et al. (2005). The lithified carbonate components are of Late Visean age (Brigantian), a little younger than the reefal buildup structures encountered at the top of well 018-01 (Cambridge Carbonates, 2002).

\section{S05-01}

Description Seven cores were taken in the carbonate interval in the S05-01 well. Core \#7 contains dark-grey to black bioclastic, bioturbated limestones with thick bivalves, which are locally slightly dolomitised. Horizontal stylolites and mouldic porosity are present at $1906 \mathrm{~m}$. Core \#6 contains large bioclastic beds with a fining-up trend from centimetre-sized peloids to 'micritic' carbonate mud (at $1781 \mathrm{~m}$ ). Horizontal stylolites and filled vertical fractures occur sporadically. Black shales with tiny (mmsize) shells are present at some levels (1800 and $1788 \mathrm{~m}$ ) and correspond to small gamma-ray peaks. The interval is strongly bioturbated. The subsequent core \#5 shows dark grey crinoidal, bioturbated wacke- and packstones with thick bivalves (1-2 cm) and rare coral and bryozoan fragments. In core \#4, light-to darkbrown oncoid-peloid grainstones with thick-walled shell fragments (up to $5 \mathrm{~cm}$ ) occur that at times are replaced by cryptocrystalline silica (chert) (Fig. 7C). The grainstones occasionally contain crinoids $(2-3 \mathrm{~cm})$ and lithoclasts. Higher up in core $\# 3$ and \#2, the grainstones are beige-coloured with 'clean' cement and contain large shells, fine crinoidal debris and peloids. The layers show regular stylolitic surfaces. The topmost $50 \mathrm{~m}$ of core \#1 contains cream-coloured to brown bioclastic wackestones and grainstones with abundant crinoids, calcite-filled fractures and fine shell debris (Fig. 7D). At several levels (1332, $1224 \mathrm{~m}$ ) abundant high-angle fractures are present.

Interpretation The cored sections in well S05-01 represent a shallowing-upward sequence from a deep-water, fine-grained siliciclastic basin with slope processes to a shallow-water, highenergy carbonate environment (Table S1). The siliciclasticcarbonate transition was not cored, but shows a spiky gammaray signal (Fig. 6), possibly indicative of an interfingering of shale and carbonate facies. The cyclic alternation of bioclas- 
tic grainstones grading into mudstones is similar to those observed in well KTG-01, and interpreted as sea-level variations inducing shifts between shallow marine subtidal, to lagoonal and tidal mudflat deposit environments. These are overlain by open marine wackestones, which towards the top alternate with lighter-coloured grainstones, interpreted as lagoonal and highenergetic barrier facies, respectively. Significant compaction took place as is represented by abundant bedding-parallel horizontal stylolites. The increasing abundance of clean grainstones (Fig. 7D) at the very top of the cored sections indicates the presence of a carbonate shoal. In the light of observations in other wells, the absence of significant karst surfaces and pedogenic structures in this interval is remarkable.

\section{BHG-01}

Description Two cores were taken in the carbonates in this well that were described by the Rijks Geologische Dienst (RGD, 1978). The sediment in core \#2 consists of dark grey limestone; highly compacted grains and microstylolites are common. Most bioclastic grains are diagenetically altered and recrystallised. The packand grainstones at the base of the core $(2387 \mathrm{~m})$ are heavily fractured; brecciated parts of limestone are floating in a calcite vein filling. Fracture cavities are not completely cemented, some relict porosity remains, while mineralisations of galena $(\mathrm{PbS})$ are also present within the veins. Core \#1 also contains heavily brecciated carbonates with fractures and both horizontal and high-angle $\left(\sim 40^{\circ}\right)$ stylolites (Fig. $\left.7 \mathrm{E}\right)$. The carbonates contain crinoids and bryozoans as well as large intraclasts and lithoclastic material (Fig. 7F). Cavernous porosity is infilled by barite, pyrite, galena and dolomite-quartz precipitates. Local concentrations of bitumen were observed in the cavities and fractures (RGD, 1978). Towards the top of the core the amount of finegrained siliciclastics increases.

Interpretation The lower core is heavily fractured and veined, and shows multiple signs of dissolution and recrystallisation. Although the sediment resembles a fine grainstone, the dissolution hampers interpretation of the original sedimentary structures. Despite its dark colour, NAM (1982) originally interpreted this section as a high-energy grainstone barrier (Table S1). An Early Visean (Chadian) age is obtained from the foraminiferal assemblage. Dolomites with a plausible Tournaisian age are present below this core interval, but were not cored (RGD, 1978). The cored interval strongly resembles the lower part of well 018-01 containing dark wacke- and packstones, heavily influenced by compaction and solution processes, therefore a similar origin is proposed: deposition took place on a shallow, low-relief carbonate ramp below or near wave base.

The upper core is heavily fractured, brecciated and contains numerous veins and mineralisations at various levels. Stylolites have developed both horizontally and at a moderate angle $\left(\sim 40^{\circ}\right)$. The latter type is possibly developed along sites of contrasting lithologies, and could represent sedimentary bedding (Fig. 7E). NAM (1982) interpreted these deposits as reefal mud build-ups and lower slope sediments. The sediments resemble the boulder-beds and bioclastic alternations found in the upper cores of well S02-02; a similar Late Visean (Asbian) age was assigned to this facies (RGD, 1978). This was a period of high-amplitude cyclic glacioeustatic sea-level variations, which favoured reworking of carbonates. Similar, time-equivalent stylolitised 'welded' microbial carbonate breccias are observed in the fractured slope sediments of the Caspian region (Kenter et al., 2005; Harris et al., 2008).

The RGD (1978) interpreted the mineralised carbonate breccias (Fig. 7F) as post-diagenetic karst features, formed during a Late Visean to Early Namurian erosional period, stating they resembled the Windy Knoll carbonates of Derbyshire (UK), where Carboniferous limestones containing economic calcite, galena, fluorite and barite mineralisations are exposed (Ford \& King, 1965). The presence of bitumen in the strongly mineralised carbonates of well BHG-01 indicate that porosity creation and charging of hydrocarbons occurred in the right order and provides another similarity to the carbonates of Windy Knoll, in which fluid inclusion analyses indicated that the hydrocarbons were co-genetic with a hydrothermal mineralising brine (Moser et al., 1992). We interpret the mineralised carbonates of well BHG-01 as post-diagenetic hypogene karstification phase sensu Klimchouk (2017), which concentrated in the lithified, redeposited microbial slope sediments of Late Visean age.

\section{KTG-01}

Description A single core of c. $50 \mathrm{~m}$ was taken in the KTG-01 well. The Rijks Geologische Dienst report (RGD, 1983) was used as reference. Core \#4 (1900.0-1891.5 m) contains dark-grey to black layers of laminated clay and siltstone. Generally, the siltstone layers are lighter-coloured and have slight erosional bases. Deformed flaser beds are recognised in some intervals. Calcite veins intersect the whole core. Core \#3 (1735.0-1720.3 m) comprises dark-grey siltstone with abundant calcite veins and small cavities that are partially filled with minerals (geodes). Overall the sedimentary bedding is poorly developed and the sediment is clearly disturbed at some levels. Core \#2 (1365.1-1351.0 m) shows a well-laminated succession of grey to dark-grey siltstones with occasional disturbed bedding. The sediments show reworking of partly lithified sediments and small slump structures. The uppermost core \#1 (995.6-946.90 m) spans c. $50 \mathrm{~m}$ and mainly consists of dolomite. The grade of dolomitisation varies throughout the sequence, and the full spectrum from pure limestone to $100 \%$ dolomite is present. However, in the largest part of cores dolomitisation developed slightly to moderately well. At the base of this interval, bioclastic packstones with shell debris alternate with silty beds. Some strongly compacted laminated algal limestones with infilled fenestral pores are also present. In certain levels, fractures and cm-wide vein 
cements are common (Fig. 7B). In addition, exposure surfaces (at 993.3 and $974.0 \mathrm{~m}$ ) are preserved; cauliflower structures (990.6 m), stylolites and centimetre-sized vugs (at $987.5 \mathrm{~m}$ ) are also present. A strongly karstified zone (985-975 m) is present, characterised by cavernous porosity infilled with pink carbonate precipitates, glauconite sands and rubble of Cretaceous age (NAM, 1982). The top sequence shows grainstones with large shells overlain by dolomites, 'chickenwire' anhydrites and a calcrete soil at $951.7 \mathrm{~m}$. The very top of the core $(94.0 \mathrm{~m})$ consists of shallow marine carbonates with algal lamination and shellrich levels. Silicified levels are present throughout.

Interpretation The carbonate sequence in the KTG-01 well is thin compared to the other wells. The carbonates have been assigned an Early Visean age based on foraminifera occurrences (RGD, 1983). Tournaisian carbonates seem to be missing, although a Tournaisian age has been assigned to the nearshore siliciclastics that underlie the carbonates (RGD, 1983). The entire sequence consists of a cyclic development of restricted shallow marine to supratidal deposits (Table S1). Many internal erosional boundaries, pedogenic and karstified levels are present, suggesting that long periods of exposure were frequent. This also suggests that the preserved sequence is highly condensed. Occasionally, siliciclastic input alternated with the limestone and dolomite sediments. Overall, the sequence represents a tidal mudflat to restricted lagoon environment where bioclastic grainstones and algal laminated packstones accumulated. Based on the diminishing number of exposure surfaces, a slight deepening of the mudflat is inferred towards the top of the cored sequence, although periodic exposure still occurred. Cretaceous deposits not only unconformably overlie the Dinantian carbonates, as can be discerned in seismic data, but also penetrate the sequence as infill of cavernous karst structures. Therefore an underground karst system must have been active before and/or during the Cretaceous deposition; some of the karst structures might have been present since a Late Dinantian - Early Namurian episode of regression (Schroot et al., 2006) because vein cements partly fill the cavities (NAM, 1982). Meteoric or mixing zone karst is most likely, since after reflooding of the system marine Cretaceous sediments infilled the cavernous porosity system.

\section{CAL-GT-01}

Description and interpretation of cuttings samples This well encountered $\sim 750 \mathrm{~m}$ of Dinantian carbonates, underlain by Devonian quartzite and dolomite. The well encountered a large karst feature between 1737 and $1758 \mathrm{~m}$ depth, resulting in total losses of drilling fluids. No core was taken in this well. Sample description and microscopic analysis were reported in two unpublished documents, PanTerra (2012) and Poty (2014).

The presence of fossiliferous grainstone and packstone cuttings in the sample above the karst zone indicates deposition in shallow water, possibly still in situ or reworked after deposi- tion. Chert is present and probably derived from silicified carbonate, possibly related to bioturbated layers. The carbonates are mostly tight, except for some intercrystalline porosity in partly dolomitised carbonate and dissolution porosity in chert, which is attributed to the chertification, not the karstification. SEM analysis indicates the presence of some microporosity (PanTerra, 2012).

Severe diagenesis below the karst zone hampered microfacies interpretation, and very little biostratigraphic dating could be performed. The upper section of the Dinantian carbonates (between 1605 and $1980 \mathrm{~m}$ ) could be attributed to the Middle and Late Visean, and the lower section (between 1980 and $2350 \mathrm{~m}$ ) to the Early Visean and the Tournaisian. The recognised microfacies is mainly grainstone and wackestone, suggesting a platform or ramp setting for the entire section, but not a reef. This suggests that the (present-day) high could be due to block faulting (Poty, 2014).

The entire section below the karst shows high diagenesis, with the Visean section silicified and the supposedly Tournaisian-age section dolomitised and de-dolomitised. The quartz veins, sparry calcite and (de-)dolomite suggest that diagenesis is related to hydrothermal waters rich in silica and in calcium sulphate (the latter causing de-dolomitisation) (Poty, 2014). Geochemical analysis could not be executed due to the too small sample size.

\section{Seismic interpretation}

Seismic interpretation was performed on public 2D seismic lines covering a large part of the southern Dutch subsurface, as well as part of the Campine Basin in northern Belgium (Fig. 5). The seismic dataset includes data with large differences in quality and often lacking information on the seismic processing, which complicates the interpretation. A number of 2D lines had been digitised from paper sections, which sometimes improved the data quality and, more importantly, facilitated digital interpretation and manipulation. A limited number of wells within the study area penetrated the entire Dinantian sequence and hence only few seismic-to-well ties could be made for the entire interval.

The seismic interpretation of the Campine Basin was guided by the general structure and lithostratigraphy of the Dinantian as they were described for specific areas (Langenaeker, 2000; Laenen, 2003). Additional well data and well logs of many Belgian wells were used to provide well control on the position of the Dinantian surface.

\section{Dinantian reflectors}

The seismic interpretation mainly focused on identifying the top and base Dinantian reflectors. Only where resolution permitted were the intra-Dinantian reflectors 'Top Beveland $\mathrm{Mb}^{\prime}$ and 'Base 

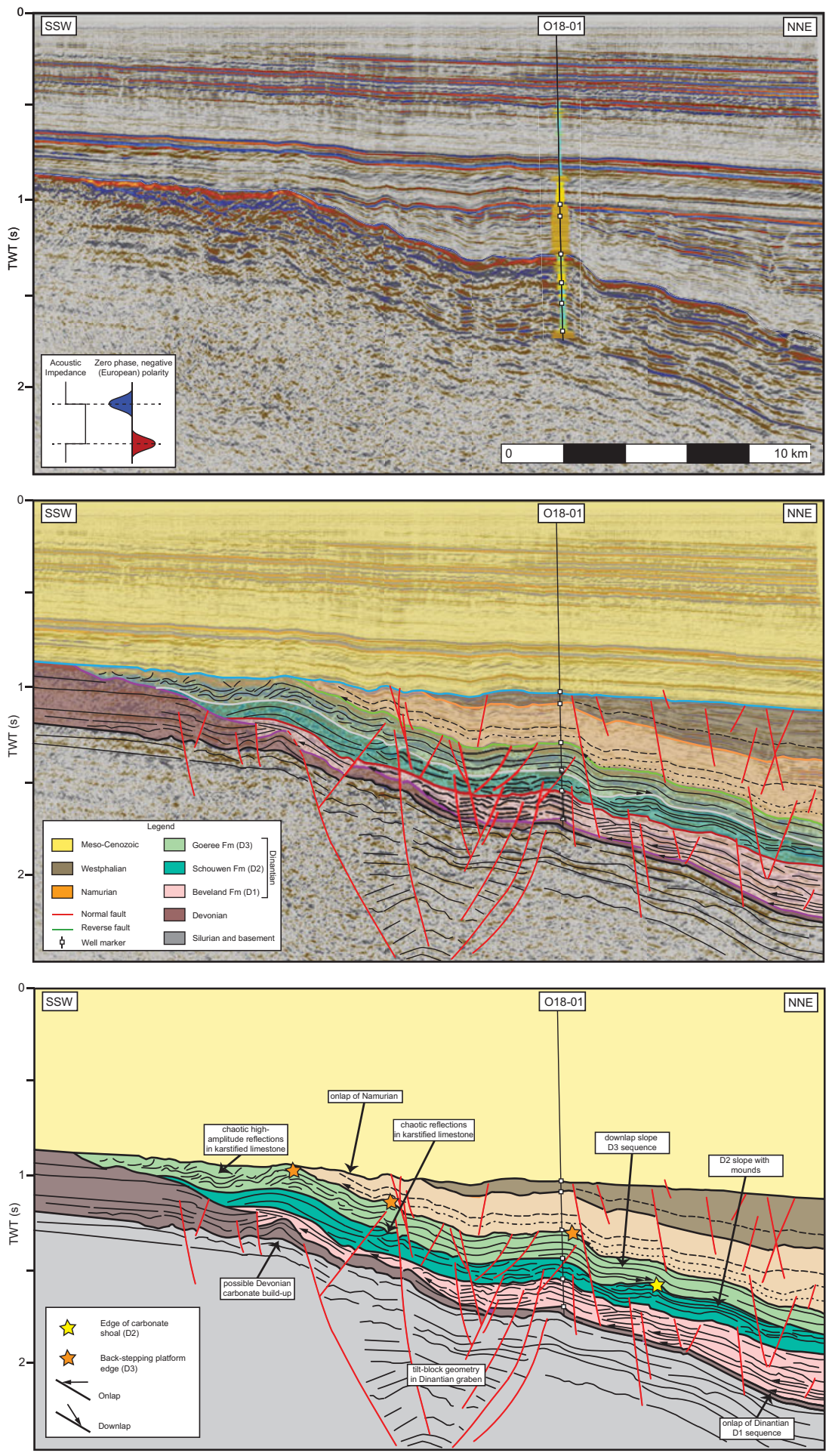

Fig. 8. SSW-NNE seismic section through well 01801 , situated in the southwestern offshore at the northern edge of the London-Brabant Massif (see Fig. 5 for location). Vertical scale in two-way time (TWT). This section illustrates the presence of a clear horizontal step in the depth of the Top Dinantian horizon, bounded by a steeper slope. Note the onlap of Dinantian strata onto the Devonian substratum and Caledonian basement. Subdivision into the Beveland, Schouwen and Goeree members is according to subdivision described in text. High-amplitude downlapping reflectors are indicative of prograding Upper Dinantian deposits. This seismic character dies out against the platform structure in the left part of the section. Highamplitude chaotic reflectors, indicative of karst, occur in the Dinantian carbonates. The highest amplitudes are associated with zones where the carbonates are truncated by the overlying Cretaceous sequence. Several chaotic reflection patterns with lower amplitudes are seen in the carbonates underlying the Silesian succession.
Goeree $\mathrm{Mb}^{\prime}$ horizons mapped, indicating the boundaries between the three different members of the Zeeland Formation sensu Van Adrichem Boogaert \& Kouwe (1993). In addition, the Top Epen Fm (top Namurian) and Base Cretaceous were often interpreted to aid in understanding the overall subsurface structure.

All seismic data used are zero-phased, negative polarity. The downward transition between Namurian shales and the Top Dinantian is represented as a hard kick and appears as a trough (blue reflector in our study) in the seismic data (Fig. 8). The base Dinantian reflector corresponds to a peak (red reflector in our study), which is explained by the downward transition from the Dinantian carbonates to the underlying clastic formations. In general the top of the Dinantian sequence can be relatively easily identified as it shows distinct onlap geometries of the overlying strata. The identification of the base Dinantian reflector, however, is more difficult because it is fairly chaotic in na- 


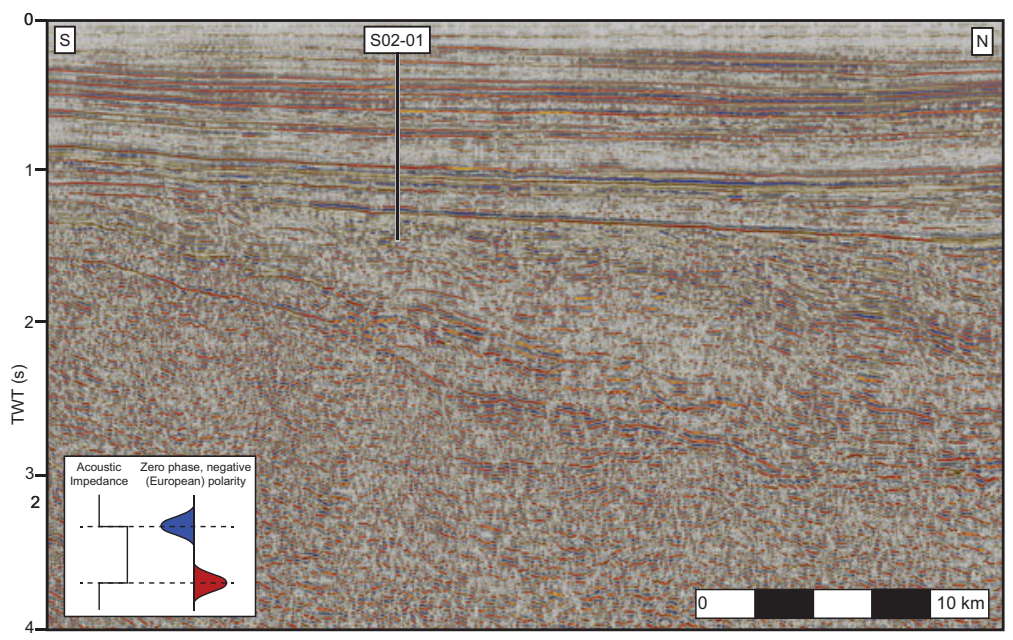

Fig. 9. S-N seismic section through well S02-01, situated in the southern offshore at the northern edge of the London-Brabant Massif (see Fig. 5 for location). Vertical scale in two-way-time (TWT). An important extensional fault below the well demarcates a half-graben basin that affected the thickness and distribution of the identified Dinantian units. The wedge shape of both the Devonian and Dinantian sequences suggests the fault was active throughout Devonian and early Carboniferous times. Drag fold structures along the same fault in the Namurian and Westphalian sequences suggest later Carboniferous activity as well. Two small, stacked clinoforms overlying the top Dinantian may correspond to early Namurian clastic deposition along a fault-bounded edge of the London-Brabant Massif.
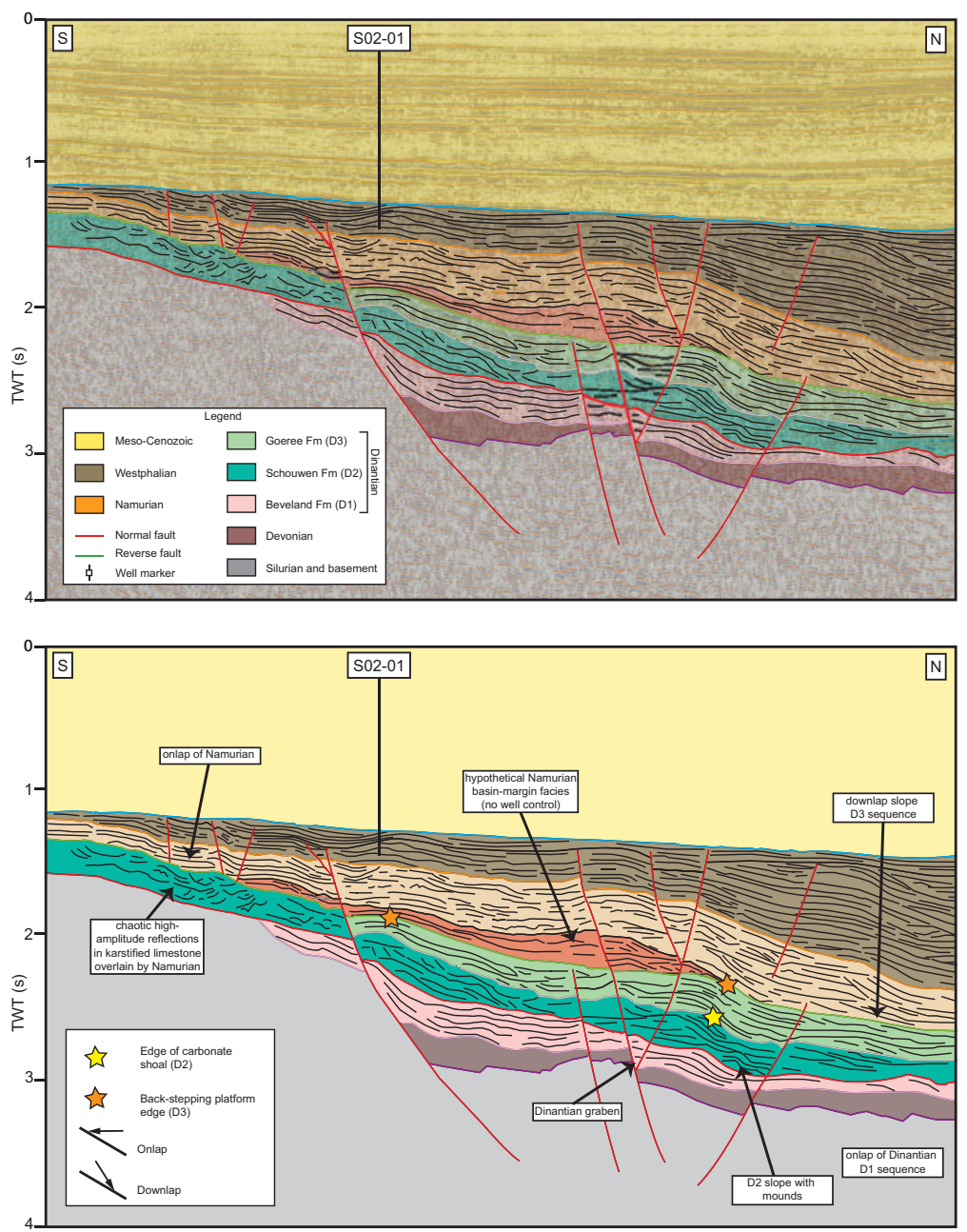

ture and the boundary at the base of the Dinantian carbonates and the underlying 'basement' is therefore diffuse.

Towards the London-Brabant Massif the reflectors tend to shallow (Fig. 9). The depth map of the Top Dinantian horizon shows a gradual deepening of the Dinantian towards the northeast (Fig. 10). The two-way time (TWT) contour lines are approximately WNW-ESE aligned, i.e. parallel to the massif. The
Base Dinantian depth map (Fig. 10) reveals a roughly similar orientation to that of the Top Dinantian, with the highest dipgradient approximately perpendicular to the outline of the massif. The depth of the Base Dinantian is usually a few hundred milliseconds below the Top Dinantian. The Dinantian is shallowest in the southeast of the study area, the Belgian Campine Basin and towards Limburg, and the dip-gradient of the sequence is 

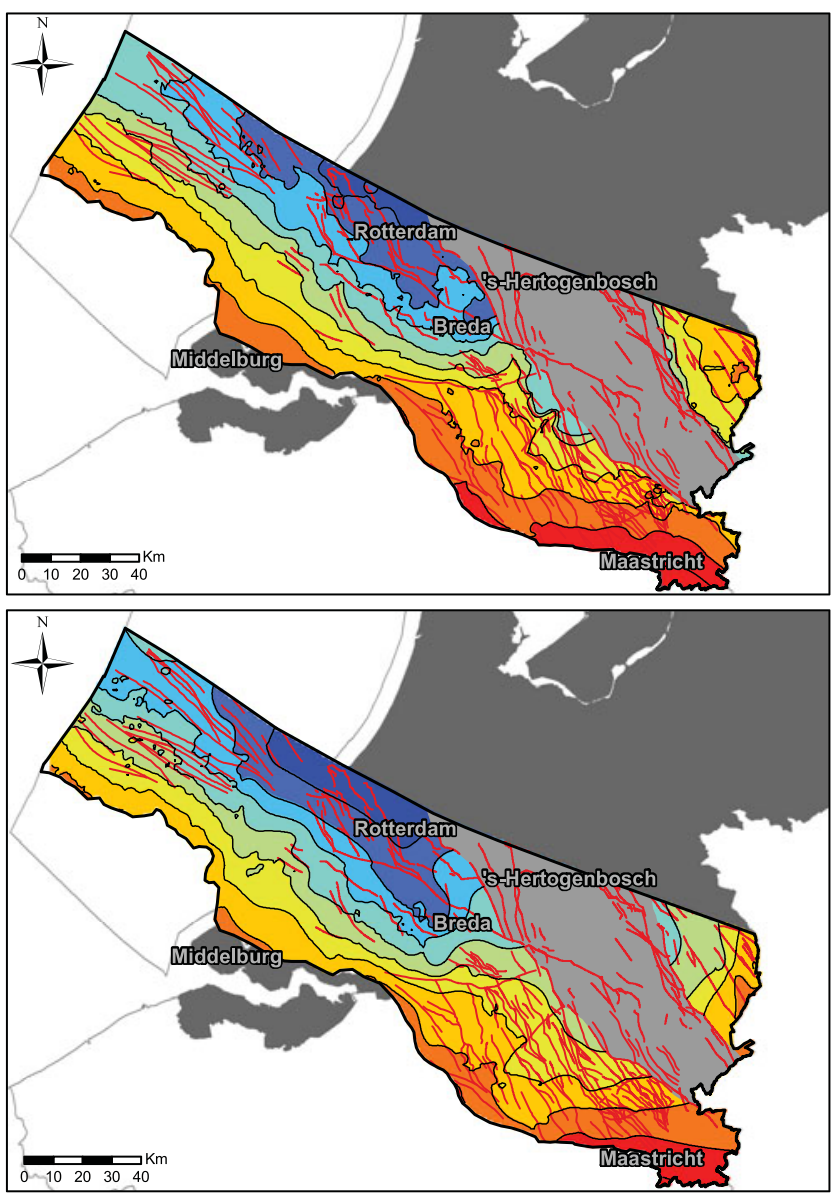
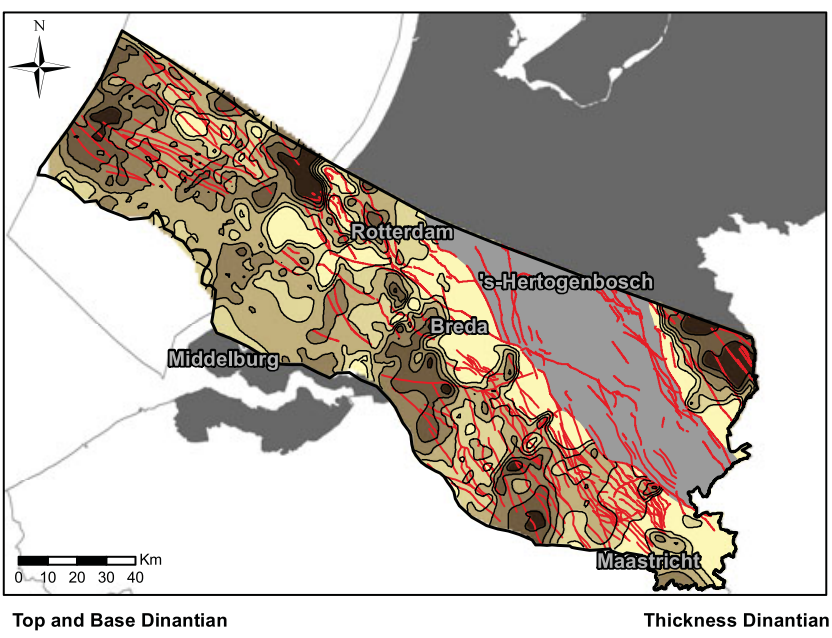

Elevation time (ms)

$\mathrm{ms}$

\begin{tabular}{|l}
$\square-500$ \\
$500-1000$ \\
$\square$ \\
$\square 00-1500$ \\
$\square$ \\
$1500-2000$ \\
$2000-2500$ \\
$\square 500-3000$ \\
$3000-3500$ \\
$3500-4000$ \\
$4000-4500$ \\
Dinantien too deep to interpret
\end{tabular}

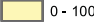

$\square 100-200$

$200-300$

$300-400$

$400-500$

$>500$

Fig. 10. Maps showing the elevation time of the interpreted top and base Dinantian horizons (top and bottom left, respectively) and the isochore thickness, both in ms. The depth classes are selected such that they approximate the actual depth (in $m$ ) to a fair degree, i.e. the depth classes in TWT are representative for actual depth classes. Note that in the centre of the Roer Valley Graben the top and base of the Dinantian cannot be interpreted in seismic data and are left blank. Fault lines (in red) represent those faults present that penetrate the top of the Dinantian; these include deep-seated syn-sedimentary faults as well as much younger ones.

much lower, as shown by the broader spacing of the contour lines. Towards the Roer Valley Graben, the Base Dinantian horizon could not be interpreted due to its large depth (i.e. not recorded in seismic data) and structural complexity.

In areas where quality and coverage of seismic data were best, two intra-Dinantian reflectors were interpreted dividing the carbonates into three sections that roughly correspond to the different members of the Zeeland Formation, i.e. the Beveland, Schouwen and Goeree members (Van Adrichem Boogaert \& Kouwe, 1993). This subdivision was prominent in the Dutch offshore on the shelf area near the London-Brabant Massif (Figs 8 and 9). The acoustic properties of these members, which are all tight carbonates, show little variation, resulting in seismic reflectors at the transitions, that are often not very pronounced. Differences in seismic quality between different surveys also hinder a consistent interpretation. In addition, karstification also significantly influenced the seismic signature of the carbonate rocks.

\section{Stratal patterns}

In the study area, the Dinantian carbonates onlap older Palaeozoic rocks: Devonian siliciclastics or the Caledonian metamorphic basement (Figs 8, 9). Seismic expression of the basement is generally very poor, with mostly 'noise' and imaged multiples of overlying formations. The basement shallows towards the SE, i.e. where the lower Palaeozoic rocks in the core of the LondonBrabant Massif are exposed (Verniers et al., 2002). Differentiation between the Devonian siliciclastics, penetrated in wells 018-01 and S02-02, and the 'proper' Lower Palaeozoic basement is difficult in seismic data as both are dominantly fine-grained siliciclastics. Towards the NE the basement deepens rapidly to over 3000 ms TWT below the present-day surface.

The Dinantian reflectors progressively onlap the northdipping basement rocks, which is interpreted as an episodic landward migration of marine deposits (coastal onlap) during a transgressive supersequence similar to that of the Tengiz field, 
Kazakhstan (Weber et al., 2003). In some locations the onlap seems to be defined by faults. Thickness anomalies in the Dinantian infill representing sub-basins that reside in the basement suggest the presence of a palaeo-relief made up by small extensional (half-graben) basins that are related to long-lived faults that have been active since at least the Devonian (Muchez et al., 1987). The presence of extensional basins where continental to marine sediments were deposited was described for the northern margin of the London-Brabant Massif (Van Adrichem Boogaert \& Kouwe, 1993; Laenen, 2003), while such deposits are absent elsewhere. The faults and sub-basins cause remarkable thickness differences in the Dinantian carbonates as shown in the isochron map for the entire Zeeland Formation (Fig. 10). Thicknesses vary from $30 \mathrm{~ms}$ near the London-Brabant Massif to over $700 \mathrm{~ms}$ in the NW part of the study area and near well RSB-01. The carbonates pinch out towards the palaeo-coastline in the southwest, which progressively onlapped the palaeo-high of the London-Brabant Massif. Since carbonate deposition is restricted by sea level, more carbonates could accumulate in the deeper parts of the basin. Initial thickness differences were enhanced by subsequent uplift of the massif, which led to erosion of the carbonate deposits, as demonstrated in well KTG-01.

In contrast to a general thickness increase to the north, the Dinantian sequence near the Halen well, towards the southern boundary of the Campine Basin, also showed a thick package in a half-graben structure (Muchez et al., 1987). These authors also divided the Campine Basin into an eastern and western part based on well observations. The Booischot, Kessel, Poederlee, Merksplas-Beerse and Heibaart wells are located in the western part. Halen is located in the eastern Campine Basin, where the Lower Dinantian deposits attain a notable thickness (Muchez et al., 1987). Seismic lines near Halen show a tilted base Dinantian while the top is near horizontal, suggesting active faulting during the early phase of carbonate deposition. This confirms tectonic basin formation since at least the Early Dinantian.

\section{Erosion surfaces}

The most important surface identified in seismic is the erosional truncation of the Carboniferous strata below Cretaceous Chalk deposits (Figs 8 and 9). This erosional surface can be traced along the entire northern margin of the London-Brabant Massif, and is easily recognised as an angular unconformity below the Cretaceous strata, which have a very characteristic seismic signal (Van der Molen, 2004). The Base Cretaceous unconformity is widely known as a regional hiatus; in the study area Upper Cretaceous chalk deposits generally overlie Pre-Permian strata. This sedimentary hiatus spans a significant amount of geologic time; the London-Brabant Massif was exposed for long periods between the Carboniferous and Cretaceous (Coward et al., 2003). However, this does not imply that sediments from intermediate time periods were never present in the study area.
In the areas where the Dinantian carbonates are not truncated by the Base Cretaceous unconformity the top Dinantian is overlain by Silesian clastics. These generally show an onlapping relationship with the carbonates. The Visean-Namurian transition is characterised by a change from carbonate to clastic deposition, and in some locations a sedimentary hiatus is known to be present (Harings, 2014). In the basinal areas the Dinantian carbonates seem more or less conformably overlain by early Namurian sediments, but on topographically higher areas a sedimentary hiatus occurs that can reach into the Westphalian (RGD, 1991). Thus, despite this locally comprehensive hiatus, seismic data of these basinal areas do not present obvious indications for a regionally important erosional surface. However, well data suggest Late Carboniferous erosional periods occurring along the fringes of the London-Brabant Massif.

No major intra-Dinantian erosion surfaces have been recognised in seismic sections. However, smaller hiatuses, below seismic resolution, might be present in the Dinantian limestones, especially within the shallower basin margin facies. Some of the studied wells (e.g. 018-01 and S05-01) showed losses at intervals of the Dinantian carbonate section, suggesting the presence of karst zones related to hiatuses. Peaks in the log data support this interpretation. Only one regional regression is known from the Early Dinantian, probably positioned at the boundary between the lower Dinantian dolomite-dominated sequence and the overlying middle to upper Dinantian (Visean) shelf carbonate sequence (Langenaeker, 2000). The boundary between these lithologies is mapped as the 'Top Beveland' Horizon.

\section{Geometries of Dinantian carbonates}

A recurrent geometry of the top-Dinantian horizons at places where carbonates are not truncated by the Base Cretaceous Unconformity is one that resembles a staircase; i.e. a series of at least two to four more-or-less horizontal plateaus occurring at different depths (in time), which are bounded by much steeper slopes, which may or may not be associated with faults (Figs 8 and 9). These structures are chiefly located near the margin of the London-Brabant Massif (also close to the UK border) where the Dinantian is at relatively shallow depth. The occurrence of different horizontal plateaus bounded by steeper slopes goes hand in hand with the occurrence of basinward-thickening, aggradational to slightly progradational carbonate build-ups. The platform boundaries are occasionally associated with faults that do not accommodate a large throw and rarely cut through the Dinantian sequence into the underlying basement. The frequent presence of such faults at the platform-slope transitions suggests faulting might have played an important role in determining the location of these sedimentary facies transitions at the platform margin.

These separate build-ups are interpreted to have developed during a locally fault-controlled deepening of the sedimentary environment. The carbonate platforms developed a back- 
stepping morphology occupying progressively more inshore and up-shelf levels during transgressions when the rate at which accommodation space is created exceeds the rate of platform growth and sediment supply (cf. Blanchon, 2011).

As such, the overall backstepping nature of the Dinantian carbonates relates to a combination of eustatic sea-level fluctuations and basin subsidence during the Late Visean. Backstepping has been observed in various foredeep basin settings (Drzewiecki \& Simó, 2002; Blanchon, 2011) and microbial carbonates (Whalen et al., 2002). This phenomenon has also been recognised in other Dinantian carbonate systems around the globe (Weber et al., 2003; Harris et al., 2008; Kombrink, 2008). In the Dutch subsurface Jaarsma et al. (2013) found indications for reef-edge rims in regional seismic lines.

Basinwards of the platforms, the internal structure of the Dinantian Goeree Member shows a downlapping geometry. The Upper Dinantian deposits downlap on a (strong) internal reflector of the Zeeland Formation overlying the more transparent facies (Figs 8 and 9). The internal downlapping reflectors are interpreted as progradational sedimentary sequences containing dominantly reworked carbonate material. This suggests that downslope transport of the sediments towards the north occurred. Progradational sequences of carbonate slope material are a common feature of $\mathrm{M}$-factory carbonates, in which slope progradation occurs independent of sea level by shedding of carbonate slope debris (Kenter et al., 2005; Della Porta et al., 2008). Initiation of slope progradation could be related to a coastal backstepping event. Global cyclic sea-level variations and tectonic movements near the London-Brabant Massif during the Late Dinantian probably enhanced mass wasting of carbonate slope material. At some locations seismics show a fanning dip, where sediments seem to have accumulated in small half-grabens bounded by extensional faults; these also indicate a northward transport of slope debris. Further basinwards, at the toe of slope, finer carbonate debris and basinal siliciclastics probably are dominant, in analogy with the sedimentation patterns found in the UK basins (Waters et al., 2009).

Well and core data have shown that clastic sediments overlie the Dinantian carbonates. These overlying strata have an onlapping relationship with the Dinantian carbonates. This is best illustrated near the platform-like structures, at the steeper slopes between the platform steps. This geometry suggests the presence of a palaeo-relief in the Dinantian carbonates during the deposition of the overlying strata. The carbonates themselves show karstic features, implying a renewed transgression following a regressive event which exposed the shallow-water carbonates after deposition. Further basinwards, away from the platforms, sedimentation could have been continuous, with basin sediments deposited over the Dinantian carbonates. The combined observations of a sedimentary hiatus, the stratal onlap patterns, observations of karstic development and presence of deltaic clastics on top of the Dinantian carbonates correspond to a well-known regional unconformity between the Dinantian carbonates and overlying Silesian clastics (Vandenberghe et al., 2000; Schroot et al., 2006; Harings, 2014). This also suggests that the unconformity is more widespread than previously proposed. In some wells the Namurian deposits are missing, and Westphalian strata directly overlie the Dinantian carbonates (Cameron, 1993). The shallow Westphalian clastics in well 01801 contain reworked Devonian sediments; erosional material derived from the London-Brabant Massif (RGD, 1991). This indicates that the hiatus described here might be complex and might include more than one erosion event.

Just north of well S02-01 (Fig. 9) two, stacked clinoform sets overlie the top Dinantian. These geometries are atypical for the draping Namurian sequence and are tentatively interpreted as Namurian low-stand clastic wedges that were deposited before renewed onlap of the London-Brabant Massif by Namurian marine shales. In the absence of well data, this notion cannot be supported; however, similar deposits have been described for the UK. Contemporaneous with northern-sourced fluviodeltaic systems of the Namurian Millstone Grit Group that fed the Central Pennine Basin, the emergent Wales-Brabant High sourced small northward-flowing fluvio-deltaic systems in Early Namurian times (Waters \& Davies, 2006).

\section{Faults}

Numerous faults dissect the Dinantian carbonates that can be related to several phases of tectonic disturbance. These faults are approximately trending NW-SE, i.e. paralleling the LondonBrabant Massif, although the poor quality of the seismic data does not always allow determining the exact relationship between the different faults systems

Most faults accommodate a relatively small (vertical) throw and affect the Dinantian carbonates as well as the overlying Silesian deposits. These intra-Carboniferous faults often detach on the pre-Carboniferous basement and may be associated with the collapse of the carbonate platform, both during deposition and later reactivation. In addition to the many small-scale faults, several faults with larger offsets are present that often originate in the lower Palaeozoic (Figs 8 and 9). On a regional scale, the larger faults divide the sequence into discrete fault blocks that, combined, arrange the different segments into a predominant NE-dipping geometry.

Syn-depositional faulting An early phase of basin deformation occurred before or during the Dinantian, as indicated by the presence of several 'pockets' recognised in the basement, i.e. grabens that were filled during the early Dinantian and covered by intra-Dinantian reflectors (Fig. 11). Often fault structures are only local; however, the basement faults dividing individual fault blocks can significantly influence the thickness of the Dinantian sequence. A large extensional fault near well S02-01 has a half-graben geometry and accommodates significant throw (Fig. 9). It displaces the 'Base Dinantian' horizon in 


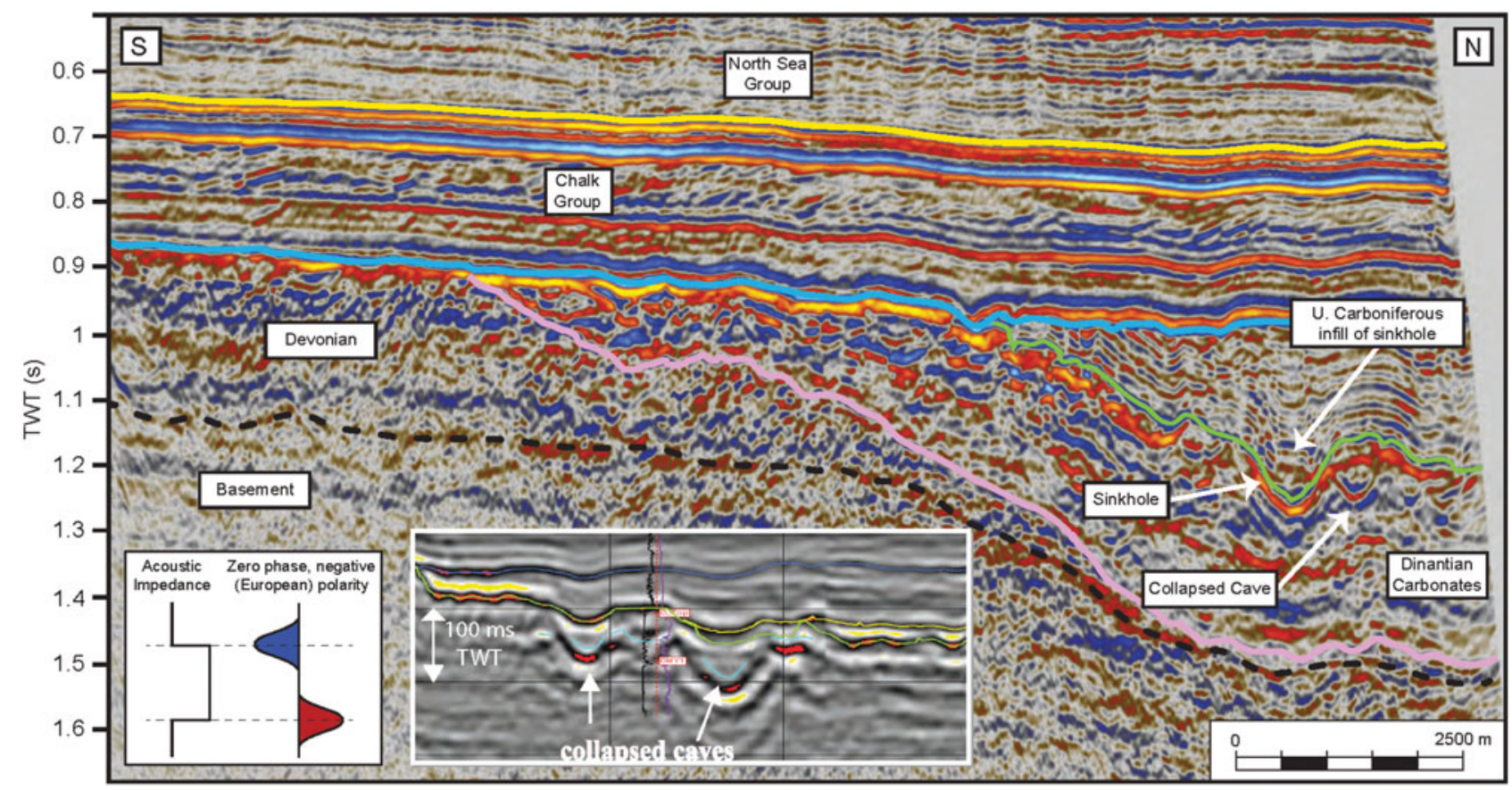

Fig. 11. S-N seismic section offshore block 018-01. Vertical scale in TWT. Here, the top of the Dinantian sequence is relatively shallow ( 1s TWT) and overlain directly by Cretaceous or Upper Carboniferous sediments. Seismic reflectors display a few concave arcs. Where these arcs coincide with the top Dinantian carbonates (green horizon) a sinkhole is interpreted, which has been filled in with younger material. A gentle sag in the Upper Carboniferous reflectors above the structure may indicate collapse of strata overlying the sinkhole. The arcs may also be positioned below the top Dinantian reflector, which suggests the presence of cavities in the carbonates. The internal reflection suggests infill or collapse of these cavities. These phenomena are similar to those observed in Ordovician carbonate reservoirs in West China which are shown in the inset (modified after Yang et al., 2010).

the hanging wall block by roughly $300 \mathrm{~ms}$ TWT along a NW-SE oriented fault. The Dinantian deposits show a pronounced thickness change, while offset of the 'Top Dinantian' horizon seems relatively minor. The reflectors in the Devonian sequence below the 'Base Dinantian' show a wedge shape, indicating the fault might already have been active during Devonian times. Devonian extensional movements along the northern margin of the London-Brabant Massif were frequently reported (e.g. Muchez \& Langenaeker, 1993; Geluk et al., 2007; Vandenberghe et al., 2014).

Additional evidence for syn-sedimentary faulting during deposition of the Dinantian carbonates is shown by the northward increase in thickness of the sequence across the onshore faults (Fig. 10). The carbonate strata wedge out towards the basin in the northeast. It thus appears that the most important fault structures are either of Dinantian origin or inherited from the Caledonian orogeny. Distinct periods of extensional movement occurred along these faults, evidenced by thickness changes. The onshore Hoogstraaten Fault (Vandenberghe, 1984) was also described as a long-lived Caledonian extension fault that defined the northern boundary of carbonate deposition during the Dinantian (Muchez et al., 1987; Vandenberghe et al., 1988; Muchez \& Langenaeker, 1993; Langenaeker, 2000). The occurrence of several extensional phases during the Dinantian period was also recognised in the UK, with the occurrence of distinct fault-blocks (TOTAL, 2007).

Post-depositional faulting Several instances of post-Dinantian tectonic disturbance have been recognised; however, these are not observable on the seismic lines shown herein. There are several faults, which significantly deform the Dinantian. Böker et al. (2012) described two sets of fault orientations. The larger faults often cut into the basement below and divide the sequence into discrete fault-blocks. These can be traced up to the Cretaceous unconformity, occasionally offsetting even the chalk and younger reflectors, indicating that these faults are very long-lived and have probably been reactivated many times.

Many smaller faults seem to have only limited effect on the Dinantian sediments; often little to no offset is visible in the seismic data used, while offsets in the overlying high-reflective Westphalian strata are more evident (Doornenbal \& Stevenson, 2010). These faults generally do not propagate above the Cretaceous unconformity; their deformation appears mostly restricted to the Silesian strata. These are interpreted as parasitic synthetic-antithetic couples and compaction-related faults that formed in the well-layered Westphalian strata above the massive and rigid Dinantian carbonate fault blocks. Some of these faults 


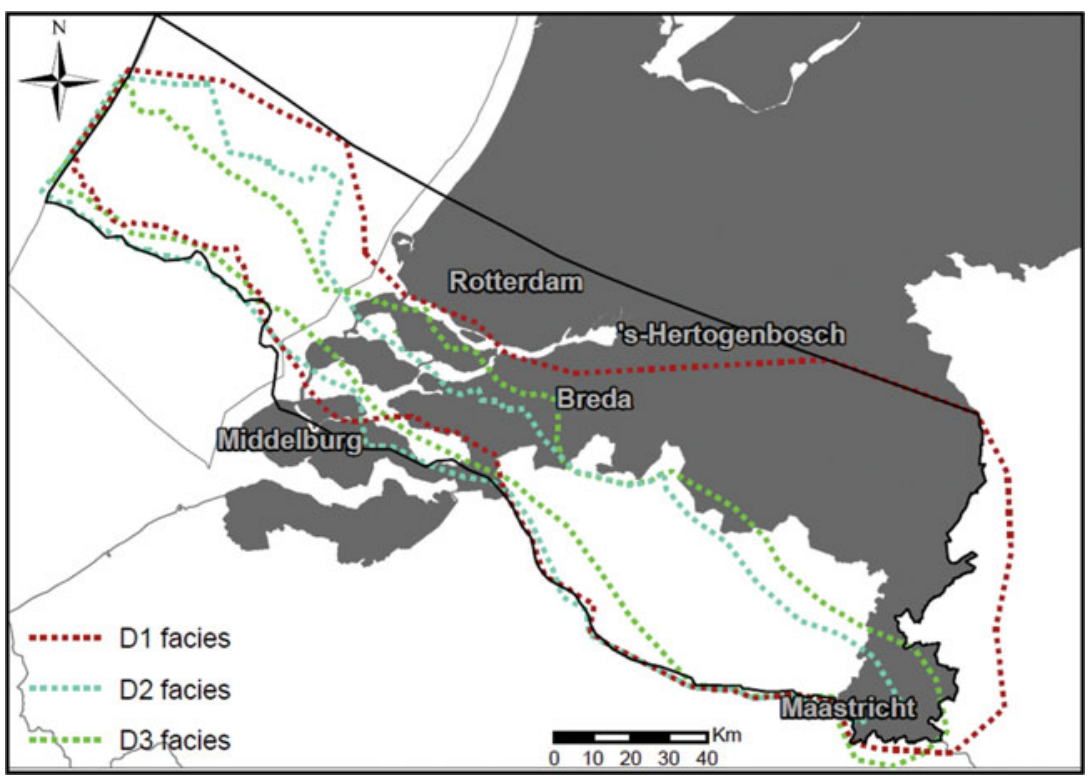

Fig. 12. Facies distribution map of the Dinantian in the entire study area. The D1, D2 and D3 facies types are broadly equivalent to respectively the Beveland, Schouwen and Goeree Members of the 'Stratigraphic nomenclature of the Netherlands' (Van Adrichem Boogaert \& Kouwe 1993). The D1 facies was recognised in well CAL-GT-01 (see Fig. 5 for location), but its continuation throughout the Roer Valley Graben is uncertain. detach onto the Dinantian or are related to distinct changes in Dinantian platform geometry.

\section{Karstification}

Although karstification is generally hard to identify, some structures that resemble karst phenomena have been recognised in the study area, especially where Cretaceous deposits directly overlie the Dinantian rocks. Anomalously high-amplitude and rather chaotic reflectors are present just below the Base Cretaceous unconformity (Fig. 8). This suggests, together with the observation of a Cretaceous infill of cavernous karst structures in KTG-01, a period of karstification prior to and contemporaneous with Cretaceous deposition. Potentially, this period could have covered more than $100 \mathrm{Myr}$, assuming that in North Belgium the exhumation of the Dinantian carbonates occurred by the end of the Palaeozoic (Vandenberghe et al., 2014). In addition, bowl-shaped depressions can be distinguished in the top Dinantian seismic reflectors (Fig. 11) in the offshore blocks near the UK-NL median line, but also in some seismic sections towards the Dutch onshore. Here, the Dinantian carbonates are directly overlain by onlapping Namurian sediments (Figs 9 and 11). In the Campine Basin this hiatus is linked to the Sudetic uplift (Graulich, 1962) and covers $\sim 1$ million years, which provides sufficient time for the development of a postDinantian meteoric karst system. Vandenberghe et al. (1986) reported on veins in karstic voids in the Dinantian sequence that are related to this karstification phase. These observations suggest that major karstification occurred during at least two periods.

\section{Facies model}

\section{Introduction}

Because of the small number of wells that have penetrated the Dinantian sequence in the subsurface of the Netherlands a comparison will be made with analogues that could provide additional insights into the different facies types present in the Dinantian carbonates. The Dinantian carbonates developed on a continuous shelf fringing the exhumed London-Brabant Massif, stretching from Ireland into Belgium and Germany. Outcrops in Belgium, Germany and the UK (Kombrink, 2008) show Visean carbonates that are situated at the southern margin of the London-Brabant Massif. The Upper Visean in this region is differently developed and partly obscured by Variscan nappe emplacement. The best outcrop analogues are found onshore UK, especially the carbonates on the northern margin of the persistent London-Brabant high, e.g. the St. George's Platform and its transition into the Craven basin (Leeder, 1976).

A lithofacies description and interpretation, and reservoir properties of the Dinantian carbonates encountered in wells, are summarised in Table S1. The characteristics of the accompanying seismic facies are shown in Figures 12 and 13 respectively. The various facies types recognised roughly correspond to the Dinantian development observed in the UK (Waters et al., 2009). The Dinantian carbonate development onshore UK shows many similarities to that found in the study area. Both successions are located on the northern flank of the LondonBrabant Massif, a continuous high, and constitute an overall transgressive sequence. The development in the study area agrees with the description given by Bridges et al. (1995), which 


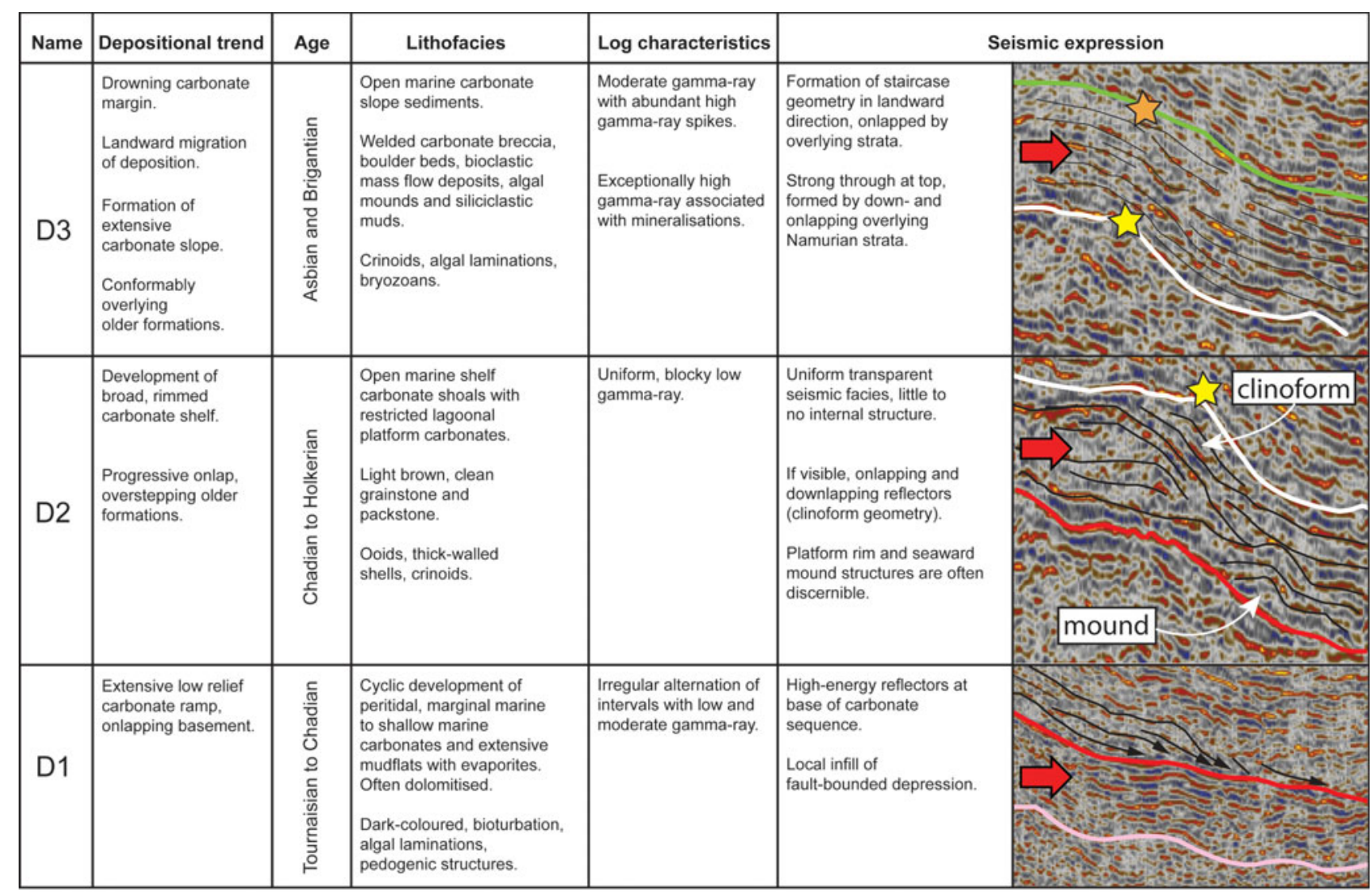

Fig. 13. Main depositional, lithofacies, log and seismic characteristics of depositional units D1-D3 recognised in the study area.

includes a carbonate ramp, rimmed platform and carbonate shelf, respectively.

\section{Comparison with analogues}

Lower Carboniferous carbonates The earliest Carboniferous deposits, the D1 facies type (Table S1; Figs 12 and 14), encountered in the study area, are of Early Dinantian age (Tournaisian and Chadian stages), which is broadly equivalent to the Beveland Members (Van Adrichem Boogaert \& Kouwe 1993). Deposits belonging to this facies type have been encountered in wells BHG-01, KTG-01, 018-01, S02-02 and S05-01.

Upper Dinantian limestones outcropping in the Peak District, on the Derbyshire high, show fringing carbonate platforms (Strank, 1987; Waters et al., 2009). These platforms continue towards the East Midlands Shelf and further to the east on the Hewett Shelf of the southern North Sea. In the study area lowgradient carbonate ramp deposits developed in a very broad, shallow marine basin setting. Within this basin, several subbasins existed, bounded by extensional faults. Cyclic, eustatic sea-level variations had a profound effect on the type of sediments deposited as a result of the low topographic basin gradient; small changes resulted in large shifts of the sedimentary environment, up to several kilometres. Sedimentation in restricted shallow marine carbonate environments alternated with periods of emergence and subaerial exposure resulting in the formation of pedogenic surfaces, karstic levels and evaporite deposition. Continued subsidence led to a gradual landward onlap of these deposits onto the London-Brabant Massif. These sedimentary conditions prevailed until well into the Chadian. The early Carboniferous carbonate deposition in the UK shows basal continental to peritidal deposits of early Visean ages, whose development already started in the Devonian. In North Wales the Visean limestone deposits progressively onlap the underlying rocks during the Visean (Waters et al., 2009).

Platform development on basin highs The Holme high is located on the northern margin of the London-Brabant Massif, on which the Chadian to Brigantian carbonates developed as distinct shallow-water carbonate platform successions (Evans \& Kirby, 1999), which may be up to $1250 \mathrm{~m}$ thick. The base shows $120 \mathrm{~m}$ of dolomite, while the top is overlain by mudstones of the Namurian Bowland Shale Formation (Waters et al., 2009). In the study area the D2 and D3 facies type (Table S1; Figs 12-14) are the time-equivalent deposits as known from the Holme high. The D2 deposits are of Middle Dinantian age (Chadian through Holkerian stages) while the latest D3 deposits are of Late Dinantian age (Asbian and Brigantian stages). The D2 and D3 facies types are broadly equivalent to, respectively, the Schouwen and Goeree Members as defined in the 'Stratigraphic nomenclature of the Netherlands' (Van Adrichem Boogaert \& Kouwe 1993). Facies type 2 deposits have been encountered in wells 


\section{D1: Tournaisian - Chadian}

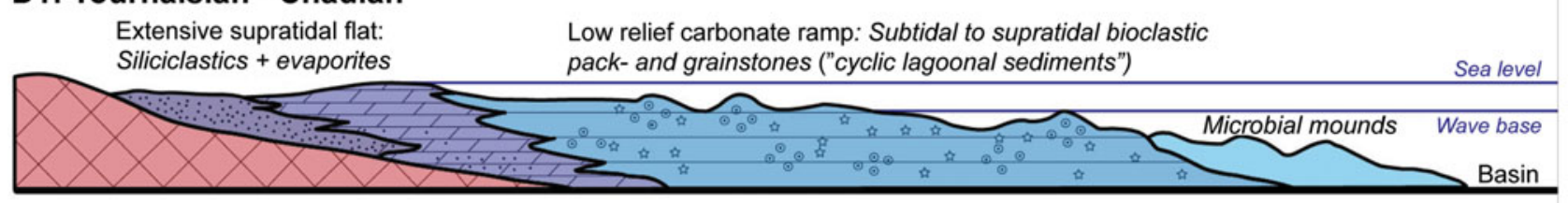

D2: Chadian - Holkerian

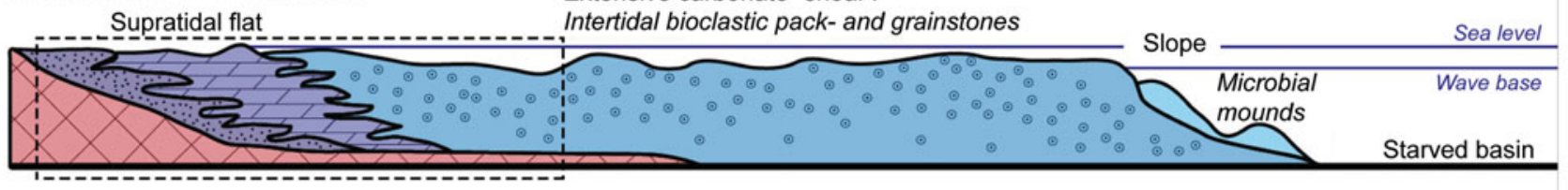

Extensive carbonate "shoal": Intertidal bioclastic pack- and grainstones

\section{D3: Asbian - Brigantian}

Intertidal lagoon

Microbial carbonate slopes:

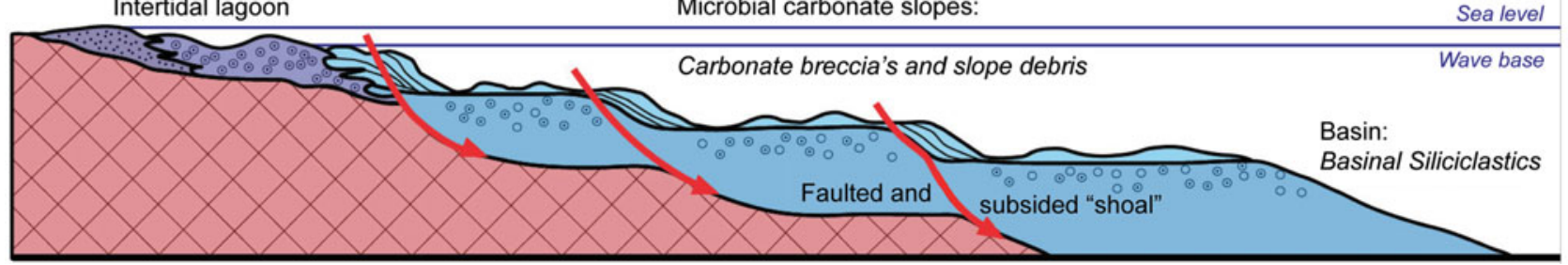

Fig. 14. Facies model of the D1, D2 and D3 Dinantian carbonate facies types occurring north of the London-Brabant Massif (not to scale). It shows the evolution from a carbonate ramp to carbonate shoal (D1) and to a broad carbonate shelf during sea-level rise (D2), followed by the drowning of the shelf (D3). Sediment descriptions of colours and symbols used provided in figure. Note the difference in scales of separate facies models. Quadrant in D2 shows extent of D3 facies type model.

BHG-01, KTG-01, 018-01, S02-02 and S05-01, while type 3 deposits were encountered in wells BHG-01, 018-01 and S02-02.

In the study area the D2 facies that developed during the Chadian, Arundian and Holkerian stages (middle Dinantian) showed sedimentation characterised by the evolution from a carbonate ramp to a rimmed shelf environment (Fig. 14). Increased subsidence in the basin led to the formation of a broad intertidal carbonate shelf. Retreat of the coastline provided the opportunity for extensive shoal complexes to build out to sea level. The increased topographic gradient allowed more distinct and narrower facies belts to develop through time. The extent of the supratidal deposits was significantly reduced while grainstone barriers protecting the lagoons were of increasing importance at the boundary of the shallow marine carbonate shelf in the southwest and the deeper marine basin to the northeast. In North Wales the Visean limestones of Chadian to Brigantian age developed as shallow marine ramp and platform carbonates that reach nearly $1 \mathrm{~km}$ thickness. At several locations the carbonate sequence developed on Silurian basement rocks of the LondonBrabant Massif (Waters et al., 2009). Development started during a transgression when peritidal and shallow lagoonal sediments formed in a carbonate ramp setting. Holkerian to Asbian lithologies are predominantly pale packstones and grainstones that contain significant amounts of shelly material and ooids; high-energy carbonates developed on a carbonate shoal with a protective barrier (Waters et al., 2009).
Repeated subaerial exposure during the late Asbian stage led to the formation of calcretes and karstic dissolution features (Waters et al., 2009). Similar sedimentation patterns occur in the study area, which are discussed in the next paragraph. On the basinal side of the protective barrier a continuous complex of knoll reefs developed during the late Asbian. This facies basically formed the slopes of the carbonate platforms, bordering a deeper basin in which debris was resedimented (Waters et al., 2009). Brigantian (Upper Dinantian / Upper Visean) deposits reflect sea-level variations in a deepening carbonate shelf environment with alternations of limestones and mudstones. This sequence is overlain by series of mixed carbonate and siliciclastic shallow-marine deposits in which karstic surfaces frequently occur. Siliciclastic channels and karstic caverns are also common, and are interpreted to result from cyclic sea-level variations in combination with an increased input of erosional material from the exposed London-Brabant Massif.

The northern margin of the London-Brabant Massif was subject to considerable subsidence during the Late Dinantian, leading to a further landward shift of the facies belts and an increase of the overall topographic gradient. Large parts of the carbonate shelf drowned and carbonate mud-mounds developed over areas that previously were occupied by carbonate shoals. The overall subsidence of the region was accompanied by the formation of normal faults, which caused the formation of a staircase submarine landscape with a significant slope environment 


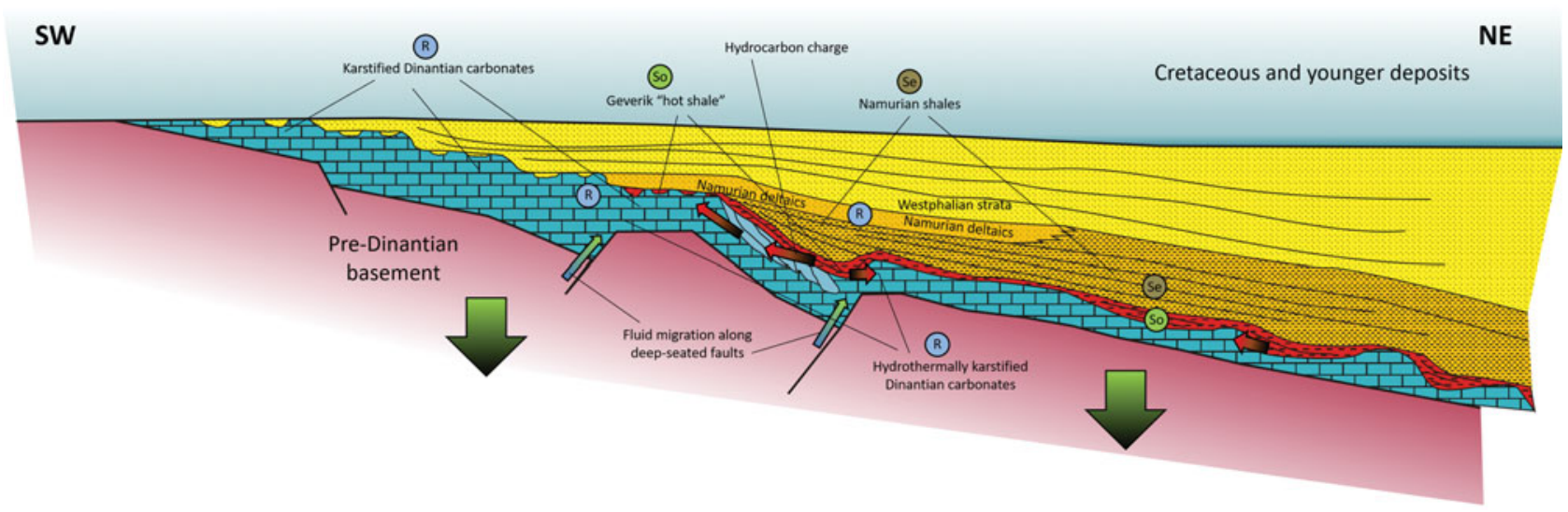

Fig. 15. Cartoon representing the main components of a possible Dinantian carbonate petroleum system on the northern flank of the London-Brabant Massif. $R=$ reservoir, So $=$ source rock, $S e=$ seal.

(Fig. 14). As for the UK part of the London-Brabant Massif, sedimentation along the slopes consisted of boulder beds and carbonate breccias deposited proximal to the platform transition and bioclastic calciturbidites in the distal parts of these slopes. Significant amounts of siliciclastic mud were deposited during periods of low carbonate input. These mass-flow deposits were incorporated in the carbonate mud-mounds and algal encrustrations of Asbian and Brigantian age. Deposits belonging to this facies type have been encountered in wells Brouwerhavensegat01, 018-01 and S02-02.

\section{Summary}

As discussed above, the differences in depositional style reflect changing palaeogeographic conditions in the Carboniferous basin, and the facies model with the D1, D2 and D3 facies types fully reflects these changes (Fig. 14). The model describes the continuous subsidence in the Carboniferous foredeep basin that during the Dinantian period was primarily instigated by the northward-propagating Variscan deformation front. The initial development of shallow marine to supratidal deposits that were subsequently dolomitised is also recognised in the Netherlands and Belgium (Langenaeker, 2000). The shallow-marine to peritidal deposits drowned in the deepest parts, while in the shallower areas they were covered by a carbonate ramp, grading from shallow marine to exposed in the south to a midand deep ramp setting towards the north. These deposits gradually onlap the exposed basement and continental siliciclastics, while the ramp evolved into a broad intertidal lagoonal shelf where periodic shoaling sequences prograde towards the north. On the shoal a protective oolitic to bioclastic grainstone barrier separated the carbonate shoal from the deeper basin. The slope area contains a well-developed complex of knoll reefs and carbonate mud-mounds. During periods of tectonic subsidence the carbonate ramps and platforms were segmented. Coarse carbonate breccias and other slope debris characterise the down- thrown blocks. Finally the carbonate platforms drown; however, the onset of basinal facies is highly diachronous while the timing of carbonate platform drowning varied. Consequently, ages for the characteristic basinal facies range from Chadian to Yeadonian.

\section{Reservoir quality and karst}

The Dinantian carbonates drilled in the Netherlands show large variations in reservoir quality (Fig. 15). In the studied cores of five wells it is mostly poor, with low average porosities and permeabilities. Measurements on cores are summarised in Table S1. Porosity is less than a few per cent, often as a result of occlusion by cementation and mineralisation, but streaks with higher porosity, over $20 \%$, are also present. Permeability is mostly very low, with a maximum of around $1 \mathrm{mD}$. Some streaks with increased permeability occur with values of up to a few $\mathrm{mD}$. Some other wells drilling the Dinantian carbonates in the Netherlands encountered (severe) losses during drilling of this section, e.g. wells 018-01, S05-01, LTG-01 and UHM-02. Sonic and gammaray logs and the porosity derived from petrophysical evaluations often show spikes at many levels. Figure 16 shows a well correlation panel with four wells to illustrate the heterogeneity in reservoir properties (EBN, 2014).

The primary reservoir quality of the Dinantian carbonates is not prominent as shown in other Dinantian carbonate build-ups (Gutteridge, 2002; Van Hulten \& Poty, 2009; Van Hulten, 2012). It has been suggested that reservoir quality might be better in the slope facies of the northern isolated platforms (Van Hulten, 2012; Hoornveld, 2013) in analogue with the Dinantian carbonate build-ups from the Caspian Sea (Weber et al., 2003; Kenter et al., 2005, Harris et al., 2008). However, the slope facies encountered in this study does not show significantly better reservoir properties. The development of secondary porosity is considered the most important factor in determining the prospec- 

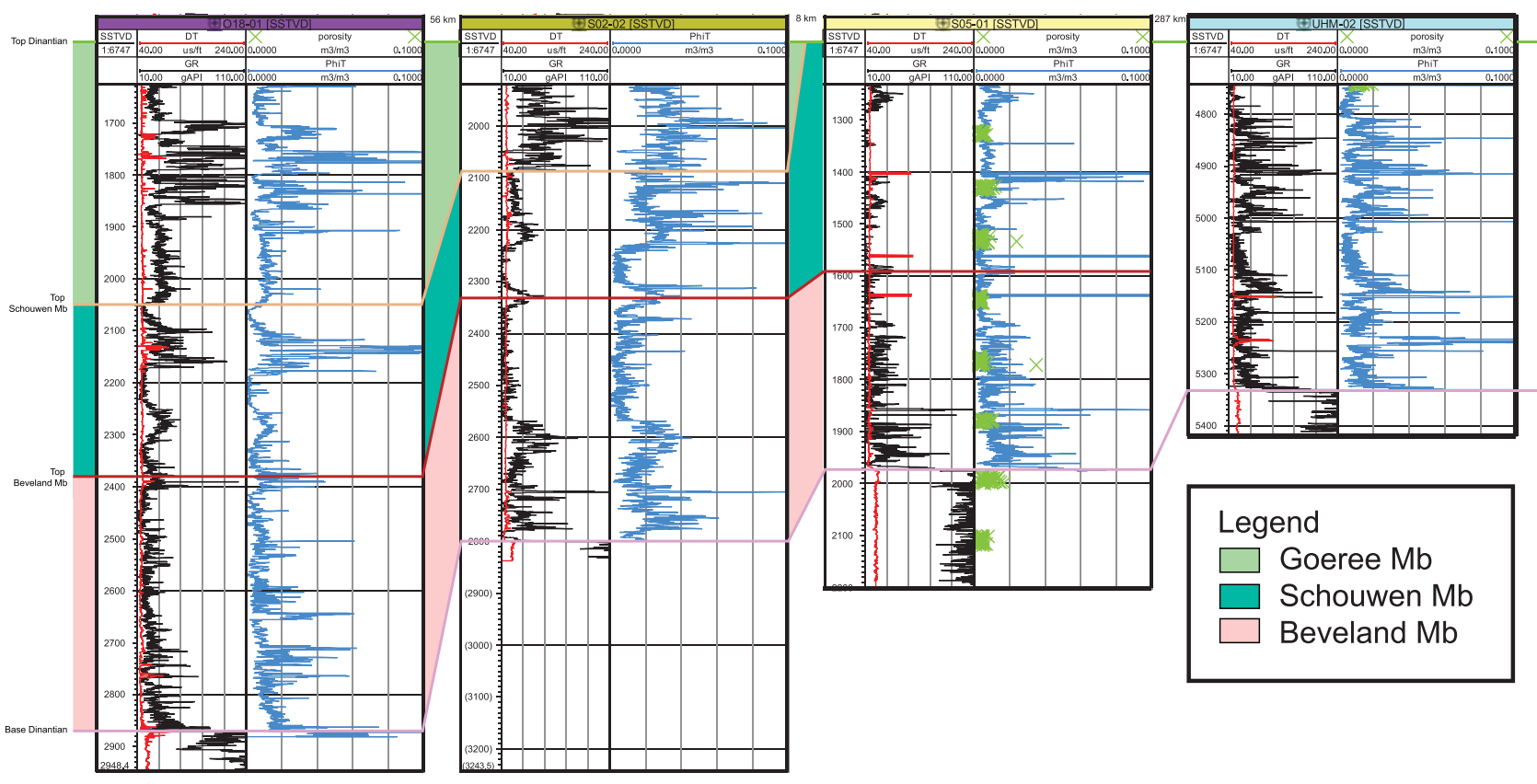

Fig. 16. Well correlation panel through wells 018-01, S02-02, S05-01 and UHM-02, flattened on top Dinantian carbonates (see Fig. 5 for locations of the wells 018-01, S02-02 and S05-01; well UHM-02 is located in the northeastern Dutch onshore). Sonic and gamma-ray logs are shown in the left pane of each well, in red and black respectively; log porosity is shown in light blue in the right panel. Green dots indicate porosities measured from cores.

tivity of the Dinantian carbonate play (Wintershall Noordzee, 2006; TOTAL 2007; Böker et al., 2012). Next to fracturing, karstification is recognised as another important process that may increase the reservoir potential of carbonates (Fig. 15).

On the northern flank of the London-Brabant Massif a widely known occurrence of a karst-enhanced Dinantian carbonate reservoir has been identified, e.g. the underground gas storage (UGS) facility near Loenhout, Belgium (Jaarsma et al., 2013). This structure occurs in the Campine Basin, and crosscutting high angle veins that were widened by karstic dissolution created porosity. This process ultimately produced cavernous porosity (Vandenberghe et al., 2000; Amantini, 2009). The karstic dissolution phase has been related to a regression at the end of the Visean period leading to regional exposure (Vandenberghe, 1984; Dreesen et al., 1987; Schroot et al., 2006) and subsequent karst development at the top of the Visean limestone in the exposed areas. The Merskplas-Beerse geothermal well positioned in these deposits shows porosities of up to $20 \%$ (Vandenberghe et al., 2000). A comparable karstic Dinantian limestone reservoir was encountered in geothermal well CAL-GT-01 drilled on the Maasbommel-Krefeld high near Venlo (Netherlands), which encountered heavily karstified sediments including metre-scale cavities (Böker et al., 2012; Jaarsma et al., 2013). Furthermore, the entire Dinantian sequence encountered in this well is strongly influenced by diagenetic changes. The Upper Visean limestones were strongly silicified ( $90 \%)$ and the Lower Dinantian section was also strongly altered. It is likely that the sediments were subjected to dedolomitisation possi- bly involving fluids rich in calcium sulphates (Poty, 2014). The occurrence of quartz and calcite veins strongly suggests that these alterations were caused by hydrothermal fluid circulation (Fig. 15), possibly associated with the emplacement of minerals (Poty, 2014). The seismic lines near the well show that the well is drilled near a fault zone, which may have facilitated the hydrothermal karstification.

Below the Cretaceous unconformity in the Dutch province of Limburg, extensively silicified Dinantian limestones and leadzinc mineralisations have been described in karstified limestones (Bless et al., 1981; Friedrich et al., 1987). Sphalerite, wurtzite, pyrite and galena, and similar mineralisations are widespread in the silicified carbonates of Dinantian age near Aachen (Germany), Vesdre (Belgium) and Ireland (Friedrich et al., 1987). The emplacement of these ores followed a postVariscan period of meteoric leaching and silicification of the limestones (Friedrich et al., 1987). Similar mineral emplacement occurrences in the Dinantian limestones are known from the UK and relate to hydrocarbon generation (Ford \& King, 1965; Moser et al., 1992). Precipitation of these minerals likely took place during a period of mixing between saline brines ascending from basement rocks and meteoric waters infiltrating along the Caledonian fault systems (Friedrich et al., 1987).

The occurrence of karst-related features in outcrops, losses during drilling in various wells (Jaarsma et al., 2013), petrophysical well data and observations in cored intervals agree with structures observed in the seismic profiles (Fig. 11; Böker et al., 2012; Jaarsma et al., 2013) that resemble collapse struc- 
tures seen in well-known karst reservoirs in China and Vietnam (Fig. 11; Wang \& Al-Aasm, 2002; Fyhn et al., 2009; Yang et al., 2010). Similar karst-related collapse structures have been identified in the Campine Basin (Dreesen et al., 1987). The features suggest that several phases of subaerial exposure and associated karstification, either by eustatic sea-level changes or due to tectonic uplift, affected the Carboniferous sediments (Dreesen et al., 1987 and references therein; Kombrink, 2008; Doornenbal \& Stevenson, 2010, p. 99; Hoornveld, 2013, p. 70).

In the Namurian, the karstified limestone landscape was reflooded and subsequently covered and infilled by Namurian clastics (Schroot et al., 2006). The Turnhout well (Fig. 5) shows an irregular karstic Dinantian limestone top draped by early Namurian clastics (Vandenberghe et al., 2000). This well is located on the Loenhout build-up, which is a carbonate shoal that developed on an uplifted basement structure (Langenaeker, 2000). Later phases of deep karstification were enhanced by continued fluid circulation along fault zones; typical hypogene karst processes as discussed by Klimchouk (2017). These fluids may have had temperatures of up to $200^{\circ} \mathrm{C}$ as shown by fluid inclusion analysis of vein calcites (Muchez et al., 1991). Assuming that no deeper burial for the top Dinantian occurred in the area in later Meso- and Cenozoic times (Van Keer et al., 1998), its maximum burial depth can be based on the estimated thickness of the Namurian and Westphalian sequence in the Campine area, which is approximately $3500 \mathrm{~m}$ (Langenaeker, 2000). The $200^{\circ} \mathrm{C}$ formation temperature for the vein carbonates is in reasonable agreement with this estimated maximum burial depth of $3500 \mathrm{~m}$ assuming a high Late Carboniferous heatflow of $84 \mathrm{~mW} \mathrm{~m}^{-2}$ (Langenaeker, 2000) and a thermal conductivity of $1.6 \mathrm{~W} \mathrm{~m}^{-1}{ }^{\circ} \mathrm{C}^{-1}$ for the Westphalian-Namurian section (cf. Dijkshoorn and Clauser, 2013). This temperature can thus be considered a rather normal burial temperature and the interpretation, as hydrothermal system cannot be confirmed. Later uplift and emersion of karst levels further enhanced the reservoir properties by dissolution (Poty, 1997; Vandenberghe et al., 2000; Amantini, 2009).

The new facies model (Figs 14 and 15) shows that the Dinantian carbonates form a continuous body on the northern flank of the London-Brabant Massif, south of the Roer Valley Graben. The carbonates often show low porosities and low permeabilities, but cross-cutting, high-angle fracture systems created some secondary porosity (Vandenberghe et al., 2000). In addition, the Upper Dinantian sediments were subjected to extensive karst processes creating cavernous karst systems with up to metre-scale cavities. Smaller karst features may be cemented by carbonate cements but at times are also infilled by Namurian shales (Amantini, 2009). Source rocks may be the basal Namurian hot shales, known as the Geverik Member (Schroot et al., 2006) and the Dinantian basinal shales (equivalent to the Bowland Shales). The elements of this petroleum play are illustrated in Figure 15. The risk of absence of quality source and seals, however, is largest in areas of late generation, while in areas of early generation the risk of destroyed traps and over-matured source rocks is the most prominent. The new facies model and the insights on reservoir developments from this study are equally relevant to studies of the potential of (ultra-deep) geothermal projects in Dinantian carbonates since these geothermal projects require good reservoir properties to be successful.

\section{Conclusions}

The study showed the presence of three carbonate facies types in a study area in the southern fringe of the Northwest European Carboniferous Basin (NWECB). Carbonate sedimentation started with a Tournaisian low-gradient carbonate ramp system (facies D1) that was succeeded by a succession in which the carbonate ramp system evolved to a rimmed shelf setting (facies D2) in the Chadian-Holkerian stages. During the Late Dinantian phase (Asbian-Brigantian) subsidence of the northern margin of the London-Brabant Massif resulted in a landward shift of the shallow-marine facies belts. The formation of normal faults during this time interval resulted in a 'staircase'shaped shallow-water platform-slope-basin profile. This process was associated with large-scale resedimentation processes (facies D3).

Several phases of karstification improved the reservoir properties of the Dinantian carbonates on the northern margin of the London-Brabant Massif. A period of regional exhumation at the end of the Dinantian seems to be associated with porosityenhancing meteoric karstification. The most intense alterations seem to be present as a deep leached horizon below the Cretaceous unconformity. This resulted in large-scale dissolution processes and hence locally very high porosities. In addition, clear evidence for hydrothermal fluid migration is found. These fluids interacted with the Dinantian limestones and resulted in locally enhanced reservoir properties, while at other places mineralisation processes occluded the porosity present in the fault zones that functioned as conduits for the brines. The timing of these phases of hydrothermal fluid circulations is poorly understood. It has been proposed that these events occur on a regional scale, but this study shows that they operate on a local scale. These findings are relevant for studies of hydrocarbon prospectivity and studies of the geothermal potential of the Dinantian carbonate system in the southern Netherlands and northern Belgium.

\section{Acknowledgements}

The Nederlandse Aardolie Maatschappij (NAM) is thanked for the use of its facilities to study core material. The Flemish Institute for Technological Research (VIT0) is thanked for access to the Belgian Campine Basin seismic survey. Technical and supporting staff at TNO in Utrecht are acknowledged for the stimulat- 
ing work environment; we especially would like to thank GeertJan Vis, Maryke den Dulk, Nora Witmans, Mart Zijp, Geert de Bruin, Hans Doornenbal and Jenny Hettelaar. Koos de Jong (VU University Amsterdam) is thanked for editing some of the figures. Jan Schneider is acknowledged for the petrophysical evaluation of Dinantian carbonates in Dutch wells. We highly appreciate the thorough and constructive comments of reviewers Henk Kombrink and Noël Vandenberghe.

\section{Supplementary material}

To view supplementary material for this article (Table S1), please visit https://doi.org/10.1017/njg.2017.33

\section{References}

Abbink, 0.A., Devuyst, F.X., Grötsch, J., Hance, L., Van Hoof, T.B., Kombrink, H., \& Van Ojik, K., 2009. The Lower Carboniferous of Key-well UHM-02, Onshore The Netherlands, and implications for regional basin development. 71st EAGE Conference and Technical Exhibition, 8-11 June 2009, Amsterdam, Netherlands. EAGE (Amsterdam).

Amantini, E., 2009. Development of the performance of the Loenhout UGS (Antwerp, Belgium). 24th World Gas Conference, 5-9 0ctober 2009, Buenos Aires, Argentina. Conference proceedings.

Aretz, M., 2016. The Kulm Facies of the Montagne Noire (Mississippian, southern France). In: Denayer, J. \& Aretz, M.. (eds): Devonian and Carboniferous research: homage to Professor Edouard Poty. Geologica Belgica 19 (1-2). doi: 10.20341/gb.2015.018.

Aretz, M. \& Chevalier, E., 2007. After the collapse of stromatoporid-coral reefs - the Famennian and Dinantian reefs of Belgium: much more than Waulsortian mounds. In: Álvaro, J.J., Aretz, M., Boulvain, F., Munnecke, A., Vachard, D. \& Vennin, E. (eds): Palaeozoic reefs and bioaccumulations: climatic and evolutionary controls. Geological Society of London Special Publication 275: 143-168.

Author Unknown, 1978. Core analysis Brouwershavensegat 1. Retrieved from www. nlog.nl.

Author Unknown, 1981. Core analysis S 5-1. Retrieved from www.nlog.nl.

Author Unknown, 1982. Core analysis report well Kortgene 1. Retrieved from www. nlog.nl.

Blanchon, P., 2011. Back-stepping. In: Hopley, D. (ed): Encyclopedia of modern coral reefs. Encyclopedia of Earth Sciences Series. Springer Netherlands (Dordrecht): 77-84.

Bless, M.J.M., Boonen, P., Bouckaert, J., Brauckmann, C., Conil, R., Dusar, M., Felder, P.J., Felder, W.M., Goekdag, H., Kockel, F., Laloux, M., Langguth, H.R., Van Der Meer Mohr, J.P.M., Meesen, T., Op Het Veld, F., Paproth, E., Pietzner, H., Plum, J., Poty, E., Scherp, A., Schulz, R., Streel, M., Thorez, J., Van Rooijen, P., Vanguestaine, M., Vieslet, J.L., Wiersma, D.J., WinklerPrins, C.F. \& Wolf, M., 1981. Preliminary report on Lower Tertiary-Upper Cretaceous and Dinantian-Famennian rocks in the boreholes Heugem-1/1a and Kastanjelaan-2 (Maastricht, the Netherlands). Mededelingen Rijks Geologische Dienst 35: 333-415.
Bless, M.J.M., Bouckaert, J. \& Paproth, E., 1983. Recent exploration in PrePermian rocks around the Brabant Massif in Belgium. The Netherlands and the Federal Republic of Germany. In: Kaasschieter, J.P.H. \& Reijers, T.J.A. (eds): Petroleum geology of the southeastern North Sea and the adjacent onshore areas. Geologie en Mijnbouw (The Hague): 51-62.

Böker, U., Dijksman, B. \& van den Graaff, E., 2012. Winterton area Dinantian prospectivity review, technical summary and concepts for reservoir models, Project G977. PanTerra Geoconsultants (Leiderdorp).

Bridges, P.H., Gutteridge, P. \& Pickard, N.A.H., 1995. The environmental setting of Early Carboniferous mud-mounds. In: Monty, C.L.V., Bosence, D.W.J., Bridges, P.H. \& Pratt, B.R. (eds): Carbonate mud-mounds: their origin and evolution. International Association of Sedimentologists Special Publication 23: 171-190.

Buggisch, W., 1991. The global Frasnian-Famennian «Kellwasser Event». Geologische Rundschau 80: 49-72.

Burgess, P.M. \& Gayer, R.A., 2000. Late Carboniferous tectonic subsidence in South Wales: implications for Variscan basin evolution and tectonic history in SW Britain. Journal of the Geological Society 157(1): 93-104.

Cambridge Carbonates Ltd, 2002. Dinantian depositional systems and exploration potential. Unpublished report. Nederlandse Aardolie Maatschappij (Assen).

Cameron, N. \& Ziegler, T., 1997. Probing the lower limits of a fairway: further pre-Permian potential in the southern North Sea. In: Ziegler, K., Turner, P. \& Daines, S.R. (eds): Petroleum geology of the southern North Sea: future potential. Geological Society of London Special Publication 123: 123141.

Cameron, T.D.J., 1993. Chapter 5, Carboniferous and Devonian of the southern North Sea. In: Knox, R.W.O.B. \& Cordey, W.G. (eds): Lithostratigraphic nomenclature of the UK North Sea. British Geological Survey (London).

Choquette, P.W. and Pray, L.C., 1970. Geologic nomenclature and classification of porosity in sedimentary carbonates. American Association of Petroleum Geologists Bulletin 54(2): 207-250.

Coward, M.P., 1993. The effect of Late Caledonian and Variscan continental escape tectonics on basement structure, Paleozoic basin kinematics and subsequent Mesozoic basin development in NW Europe. In: Parker, J.R. (ed.): Petroleum geology of Northwest Europe: proceedings of the 4th Conference. Geological Society of London (London): 1095-1108.

Coward, M.P., Dewey, J., Hempton, M. \& Holroyd, J., 2003. Tectonic evolution. In: Evans, D.J., Graham, C., Armour, A. \& Bathust, P. (eds): The millennium atlas: petroleum geology of the central and northern North Sea. Geological Society of London (London): 17-33.

Della Porta, G., Kenter, J.A.M. \& Harris, P.M., 2008. Non-actualistic carbonate deposystems: revising the carbonate factory-depth paradigm. Search and Discovery Article \#40290.

Della Porta, G., Merino-Tomé, O., Kenter, J.A.M. \& Verwer, K., 2013. Lower Jurassic microbial and skeletal carbonate factories and platform geometry (Djebel Bou Dahar, High Atlas, Morocco). In: Verwer, K., Playton, T.E. \& Harris, P.M. (eds): Deposits, architecture, and controls of carbonate margin, slope, and basinal settings. SEPM (Society for Sedimentary Geology) (Tulsa, OK): 238264.

Dijkshoorn, L. \& Clauser, C., 2013. Relative importance of different physical processes on upper crustal specific heat flow in the Eifel-Maas region, Central Europe and ramifications for the production of geothermal energy. Natural Science 5: 268-281. 
Doornenbal, H. \& Stevenson, A., 2010. Petroleum geological atlas of the southern Permian Basin Area. EAGE Publications (Houten): 352 pp.

Dreesen, R., Bouckaert, J., Dusar, M., Soille, J. \& Vandenberghe, N., 1987. Subsurface structural analysis of the late-Dinantian carbonate shelf at the northern flank of the Brabant Massif (Campine Basin, N-Belgium). Memoirs of the Geological Survey of Belgium. Ministerie van Economische Zaken, Bestuur van het Mijnwezen, Belgische Geologische Dienst (Brussels).

Dronkers, A.J., Graves, W. \& Standing, D.W., 1984. S02-02: Final Geological Report, Mobil Producing Netherlands Inc. Retrieved from www.nlog.nl.

Drzewiecki, P.A. \& Simó, J.A., 2002. Depositional processes, triggering mechanisms and sediment composition of carbonate gravity flow deposits: examples from the Late Cretaceous of the south-central Pyrenees, Spain. Sedimentary Geology 146(1-2): 155-189.

Dunham, R.J., 1962. Classification of carbonate rocks according to depositional texture. In: Ham, W.E. (ed.): Classification of carbonate rocks. American Association of Petroleum Geologists Memoir 1: 108-121.

EBN (Energie Beheer Nederland), 2014. Petrophysical evaluation of the Dinantian carbonates. Unpublished.

Evans, D.J. \& Kirby, G.A., 1999. The architecture of concealed Dinantian carbonate sequences over the Central Lancashire and Holme highs, northern England. Proceedings of the Yorkshire Geological Society 52: 297-312.

Ford, T.D. \& King, R.J., 1965. Layered epigenetic galena-barite deposits in the Golconda mine, Brassington, Derbyshire, England. Economic Geology 60: 16861701.

Fraser, A.J. \& Gawthorpe, R.L., 1990. Tectono-stratigraphic development and hydrocarbon habitat of the Carboniferous in northern England. In: Hardman, R.F.P. \& Brooks, J. (eds): Tectonic events responsible for Britain's oil and gas reserves. Geological Society of London Special Publication 55: 4986.

Friedrich, G., Bless, M.J.M., Vogtmann, J. \& Wiechowski, A., 1987. Lead-zinc mineralization in Dinantian rocks of boreholes Thermae 2000 and Thermae 2002 (Valkenburg a/d Geul, the Netherlands). Annales de la Société Géologique de Belgique 110: 59-75.

Fyhn, M.W., Boldreel, L. O. \& Nielsen, L.H. 2009. Tectonic and climatic control on growth and demise of the Phanh Rang Carbonate Platform offshore south Vietnam. Basin Research 21(2): 225-252.

Gallagher, S.J. \& Somerville, I., 2003. Lower Carboniferous (Late Visean) platform development and cyclicity in southern Ireland: foraminiferal biofacies and lithofacies evidence. Rivista Italiana di Palaeontologiae Stratigrafia, 109(2): 159-171.

GAPS Nederland B.V., 1991. Final report conventional core analysis well: 0/18a-1 Placid International 0il Ltd. Retrieved from www.nlog.nl.

Geluk, M.C., Dusar, M. \& de Vos, W., 2007. Pre-Silesian. In: Wong, T.E., Batjes, D.A.J. \& de Jager, J. (eds): Geology of the Netherlands. Royal Netherlands Academy of Arts and Sciences (KNAW) (Amsterdam): 27-42.

Graulich, J.M., 1962. La phase sudète de l'0rogène varisque dans le synclinorium de namur à l'Est du Samson. Bulletin de la Société Belge de Géologie 71(2): 181-199.

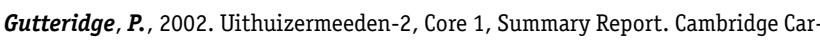
bonates Limited (Cambridge).

Harings, M.J., 2014. CAL-GT-01 - implications for the distribution of the Early Namurian Geverik Member in the Netherlands. 76th EAGE Conference \& Exhibition, 16-19 June 2014, Amsterdam, Netherlands. EAGE (Amsterdam): 1-4.
Harris, P.M., Garber, R.A. \& Clark, M.E., 2008. Geologic framework for the Tengiz and Korolev isolated carbonate platforms, Kazakhstan. Search and Discovery Article \#20060.

Heckel, P.H. \& Clayton, G., 2006. The Carboniferous System. Use of the new official names for the subsystems, series, and stages. Geologica Acta 4(3): 403-407.

Hoornveld, N., 2013. Dinantian carbonate development and related prospectivity of the onshore Northern Netherlands. Vrije Universiteit Amsterdam (Amsterdam): $142 \mathrm{pp}$.

Jaarsma, B., Brolsma, M.J., Hoetz, G. \& Lutgert, J.E., 2013. Exploring Dinantian carbonates in the SNS - new data offering new insights. 75th EAGE Conference \& Exhibition incorporating SPE EUROPEC, 10-13 June, London, UK. EAGE (London).

Kenter, J.A.M., Harris, P.M. \& Della Porta, G., 2005. Steep microbial boundstonedominated platform margins: examples and implications. Sedimentary Geology 178: 5-30.

Klimchouk, A., 2017. Types and settings of hypogene karst. In: Klimchouk, A., Palmer, A.N., Waele, J.D., Auler, A. S. \& Audra, P. (eds): Hypogene karst regions and caves of the world. Springer Nature (Cham): 1-39.

Kombrink, H., 2008. The Carboniferous of the Netherlands and surrounding areas; a basin analysis. GEOLOGICA ULTRAIECTINA, Mededelingen van de Faculteit Geowetenschappen 294. Universiteit Utrecht (Utrecht): 184 pp.

Kombrink, H., Leever, K.A., van Wees, J.-D., van Bergen, F., David, P. \& Wong, T.E., 2008a. Late Carboniferous foreland basin formation and Early Carboniferous stretching in Northwestern Europe: inferences from quantitative subsidence analyses in the Netherlands. Basin Research 20(3): 377396.

Kombrink, H., van Os, B.J.H., van der Zwan, C.J. \& Wong, T.E., 2008b. Geochemistry of marine and lacustrine bands in the Upper Carboniferous of the Netherlands. Netherlands Journal of Geosciences 87(4): 309-322.

Kombrink, H., Besly, B.M., Collinson, J.D., Den Hartog Jager, D.G., Drozdzewski, G., Dusar, M., Hoth, P., Pagnier, H.J.M., Stemmerik, L., Waksmundzka, M.I. \& Wrede, V., 2010. Carboniferous. In: Doornenbal, J.C. \& Stevenson, A.G. (eds): Petroleum geological atlas of the Southern Permian Basin Area. AEGE Publications b.v. (Houten): 81-99.

Laenen, B., 2003. Lithostratigrafie van het pre-Tertiair in Vlaanderen, Deel II Dinantiaan en

Devoon, Study commissioned by ANRE, 2003/ETE/R/095 - VITO. See also http: //ncs.naturalsciences.be/carboniferous/dinantian-campine-basin\#.

Langenaeker, V., 2000. The Campine Basin. Stratigraphy, structural geology, coalification and hydrocarbon potential for the Devonian to Jurassic. Aardkundige Mededelingen 10. Leuven University Press(Leuven).

Leeder, M.R., 1976. Sedimentary facies and the origins of basin subsidence along the northern margin of the supposed Hercynian 0cean. Tectonophysics 36(13): 167-179.

Moser, M.R., Rankin, A.H. \& Milledge, H.J., 1992. Hydrocarbon-bearing fluid inclusions in fluorite associated with the Windy Knoll bitumen deposit, UK. Geochimica et Cosmochimica Acta 56: 155-168.

Muchez, P. \& Langenaeker, V., 1993. Middle Devonian to Dinantian sedimentation in the Campine Basin (Northern Belgium): its relation to Variscan Tectonism. In: Frostick, L.E. \& Steel, R.J. (eds): Tectonic controls and signatures in sedimentary successions. Blackwell Publishing Ltd (0xford): 171-181.

Muchez, P. \& Viaene, W., 1994. Dolomitization caused by water circulation near the mixing zone: an example from the Lower Visean of the Campine Basin 
(Northern Belgium). In: Purser, B., Tucker, M. \& Zenger, D. (eds): Dolomites: a volume in honour of Dolomieu. Blackwell Publishing Ltd (0xford)

Muchez, P., Viaene, W., Wolf, M. \& Bouckaert, J., 1987. Sedimentology, coalification pattern and paleogeography of the Campine-Brabant Basin during the Visean. Geologie en Mijnbouw 66: 313-326.

Muchez, P., Viaene, W., Bouckaert, J., Conil, R., Dusar, M., Poty, E., Soille, P. \& Vandenberghe, N., 1990. The occurrence of a microbial buildup at Poederlee (Campine Basin, Belgium); biostratigraphy, sedimentology, early diagenesis and significance for early Warnantian paleogeography. Annales de la Société Geologique de Belgique 113(2): 329-339.

Muchez, P., Viaene, W., Keppens, A.E., Marshall, J.D. \& Vandenberghe, N., 1991. Vein cements and the geochemical evolution of subsurface fluids in the Visean of the Campine Basin (Poederlee borehole, Belgium). Journal of the Geological Society 148(6): 1005-1117.

NAM (Nederlandse Aardolie Maatschappij), 1982. Sedimentological model for Dinantian carbonates. Unpublished report.

Narkiewicz, M., 2007. Development and inversion of Devonian and Carboniferous basins in the eastern part of the Variscan foreland (Poland). Geological Quarterly 51(3): 231-265.

Oncken, 0., von Winterfeld, C. \& Dittmar, U., 1999. Accretion of a rifted passive margin; the late Paleozoic Rhenohercynian fold and thrust belt (middle European Variscides). Tectonics 18(1): 75-91.

PanTerra Geoconsultants, 2012. Description and microscopic analysis of 2 cuttings samples, Well CAL-GT-01. Unpublished report EBN BV.

Poty, E., 1997. Devonian and Carboniferous tectonics in the eastern and southeastern parts of the Brabant Massif (Belgium). Aardkundige Mededelingen 8: 143-144.

Poty, E., 2014. Report on cuttings from the CAL-GT-01 borehole. Unpublished report EBN BV.

RGD (Rijks Geologische Dienst), 1978. Het Paleozoïcum van de Diepboring Brouwerhavensegat-1 (N.A.M.) tussen 1398 en 2906.8 m. Retrieved from www.nlog.nl.

RGD, 1983. Onderzoek monsters NAM-boring Kortgene-1; kerntrajecten 946.90$995.60,1351-1365.10,1720.33-1735$ en $1891.50-1900 \mathrm{~m}$. Retrieved from www.nlog.nl.

RGD, 1991. Palynological investigation of the well 018-01. Retrieved from www. nlog.nl.

Schlager, W., 2005. Carbonate sedimentology and sequence stratigraphy. SEPM Concepts in Sedimentology and Paleontology 8. SEPM (Society for Sedimentary Geology) (Tulsa, 0K): 200 pp.

Schroot, B.M., Van Bergen, F., Abbink, O.A., David, P., Van Eijs, R. \& Veld, H. 2006. Hydrocarbon potential of the Pre-Westphalian in the Netherlands onand offshore - report of the PetroPlay project. TNO-NITG (Utrecht).

Strank, A.R.E., 1987. The stratigraphy and structure of Dinantian strata in the East Midlands, UK. In: Adams, A.E., Miller, J. \& Wright, V.P. (eds): European Dinantian environments. John Wiley (Chichester): 157-175.

Swennen, R. \& Muchez, P., 1991. Sedimentological and diagenetic study of the Dinantian carbonates and underlying siliciclastics of Placid borehole 018-01. Placid International 0il, Netherlands.

TOTAL E\&P UK, 2007. A regional review of the Dinantian carbonate play: Southern North Sea \& onshore UK. Total E\&P UK.

Van Adrichem Boogaert, H.A. \& Kouwe, W.F.P., 1993. Stratigraphic nomenclature of the Netherlands, revision and update by RGD and NOGEPA. Mededelingen
Rijks Geologische Dienst 50. TNO-NITG Geological Survey of the Netherlands (Utrecht).

Van der Molen, A.S., 2004. Sedimentary development, seismic stratigraphy and burial compaction of the Chalk Group in the Netherlands North Sea area. GEOLOGICA ULTRAIECTINA. Mededelingen van de Faculteit Geowetenschappen 248. Universiteit Utrecht (Utrecht): $180 \mathrm{pp}$.

Van Hulten, F.F.N., 2012. Devono-Carboniferous carbonate platform systems of the Netherlands. Geologica Belgica 15(4): 284-296.

Van Hulten, F.F.N. \& Poty, E., 2008. Geological factors controlling Early Carboniferous carbonate platform development in the Netherlands. Geological Journal 43: 175-196.

Van Hulten, F.F.N. \& Poty, E., 2009. Dinantian Reefs underneath the Netherlands. 71st EAGE Conference and Technical Exhibition, 8-11 June 2009, Amsterdam, Netherlands. EAGE (Amsterdam): W039: 1-5.

Vandenberghe, $N$., 1984. The subsurface geology of the Meer area in North Belgium and its significance for the occurrence of hydrocarbons. Journal of Petroleum Geology 7: 55-66.

Vandenberghe, N., Poggiagliolmi, E. \& Watt, G., 1986. Offset dependent seismic amplitudes from karst limestone in northern Belgium. First Break 4(5): 9-27.

Vandenberghe, N., Dusar, M., Laga, P.G. \& Bouckaert, J., 1988. The Meer well in North Belgium. Memoirs of the Geological Survey of Belgium 25. Ministère des Affaires économiques, Administration des Mines, Service géologique de Belgique (Brussels).

Vandenberghe, N., Dusar, M., Laga, P.G. \& Bouckaert, J., 2000. The MerksplasBeerse geothermal well (17W265) and the Dinantian reservoir. Geologica Belgica, 3(3-4): 349-367.

Vandenberghe, N., De Craen, N. \& Beerten, K., 2014. Geological framework of the Campine Basin Geological setting, tectonics, sedimentary sequences. Studiecentrum voor Kernenergie. External Report 262: 1-113.

Van Keer, I., Ondrak, R., Muchez, Ph., Bayer, U., Dusar, M \& Viaene, W., 1998. Burial history and thermal evolution of Westphalian coal-bearing strata in the Campine basin (NE Belgium). Geologie en Mijnbouw, 76: 301-310.

Verniers, J., Pharaoh, T., Adré, L., Debacker, T., de Vos, W., Everaerts, M., Herbosch, A., Samuelsson, J., Sintubin, M. \& Vecoli, M., 2002. The Cambrian to mid Devonian basin development and deformation history of eastern Avalonia, east of the Midlands Microcraton: new data and a review. In: Winchester, J.A., Pharaoh, T.C. \& Verniers, J. (eds): Palaeozoic amalgamation of Central Europe. Geological Society of London Special Publication 201: 47-93.

Wang, B. \& Al-Aasm, I.S., 2002. Karst-controlled diagenesis and reservoir development: Example from the Ordovician main-reservoir carbonate rocks on the eastern margin of the Ordos basin, China. American Association of Petroleum Geologists Bulletin 86(9): 1639-1658.

Waters, C.N. \& Davies, S.J., 2006. Carboniferous: extensional basins, advancing deltas and coal swamps. In: Brenchley, P.J. \& Rawson, P.F. (eds): The geology of England and Wales. Geological Society of London (London): 173-223.

Waters, C.N., Waters, R.A., Barclay, W.J. \& Davies, J.R., 2009. A lithostratigraphical framework for the Carboniferous successions of southern Great Britain (Onshore). British Geological Survey(London).

Weber, L.J., Francis, B.P., Harris, P.M. \& Clark, M.E., 2003. Stratigraphy, lithofacies, and reservoir distribution, Tengiz Field, Kazakhstan. In: Ahr, W.M., Harris, P.M., Morgan, W.A., \& Somerville, I.D. (eds): Permo-Carboniferous carbonate platforms and reefs. Society for Sedimentary Geology Special Publication 78. Society for Sedimentary Geology (Tulsa, 0K): 351-394. 
Whalen, M. T., Day, J., Eberli, G. P. \& Homewood, P. W., 2002. Microbial carbonates as indicators of environmental change and biotic crises in carbonate systems: examples from the Late Devonian, Alberta basin, Canada. Palaeogeography, Palaeoclimatology, Palaeoecology 181(1-3): 127-151.

Wintershall Noordzee BV, 2006. Promote Licence P1252, Two Year Report, Blocks: 53/15b, 53/19, 53/20, 54/11 \& 54/16. Wintershall Noordzee BV (Rijswijk).

Yang, H., Xue, F., Pan, W., Chen, L., Yang, P., Tong, Y. \& Zhao, C., 2010. Seismic description of karst topography and caves of Ordovician carbonate reservoirs,
Lungu area, Tarim Basin, West China. SEG Annual Meeting 2010. Society of Exploration Geophysicists (Denver, C0): 1256-1260.

Ziegler, P.A., 1990a. Geological atlas of Western and Central Europe. Shell International Petroleum Maatschappij B.V.: 237 pp.

Ziegler, P.A., 1990b. Tectonic and palaeogeographic development of the North Sea Rift system. In: Blundell, D.J. \& Gibbs, A.D. (eds): Tectonic evolution of the North Sea rifts. Oxford Science Publications (Oxford): $1-36$. 